\title{
The spring mesozooplankton variability and its relationship with hydrobiological structure over year-to-year changes (2003-2013) in the southern Bay of Biscay (Northeast Atlantic)
}

\author{
Dessier Aurélie ${ }^{1}$, Bustamante Paco ${ }^{1}$, Chouvelon Tiphaine ${ }^{2}$, Huret Martin ${ }^{3}$, Pagano Marc ${ }^{4}$, \\ Marquis Elise ${ }^{5}$, Rousseaux Frédéric ${ }^{1}$, Pignon-Mussaud Cécilia ${ }^{1}$, Mornet Francoise ${ }^{6}$, Bréret Martine ${ }^{1}$, \\ Dupuy Christine ${ }^{1, *}$
}

\footnotetext{
${ }^{1}$ Littoral Environnement et Sociétés (LIENSs), UMR 7266, CNRS-Université de La Rochelle, 2 rue Olympe de Gouges, 17042 La Rochelle Cedex 01, France

2 IFREMER, Unité Biogéochimie et Écotoxicologie (BE), Laboratoire de Biogéochimie des Contaminants Métalliques (LBCM), Rue de l'lle d'Yeu, F-44311 Nantes 03, France

${ }^{3}$ IFREMER, Unité Sciences et Technologies Halieutiques (STH), Laboratoire de Biologie Halieutique (LBH), Centre Bretagne, F-70 29280 Plouzané, France

${ }^{4}$ Institut Méditerranéen d'Océanologie (M.I.O.), UM 110, Aix-Marseille Université, CNRS/IRD, Campus de Luminy, Marseille 13288, France

${ }^{5}$ URS Qatar LLC, 22108, Bin Jaham Al Kuwari Bldg., Al Saad St., Doha, Qatar

${ }^{6}$ IFREMER, Unité Halieutique Gascogne Sud (HGS), Station de La Rochelle, Place Gaby Coll, F-17087 L'Houmeau, France

* Corresponding author : Christine Dupuy, email address : christine.dupuy@univ-Ir.fr
}

\begin{abstract}
:
Mesozooplankton can be considered the most important secondary producers in marine food webs because they hold an intermediate position between the phytoplankton assemblage and the upper trophic levels. They also are a robust indicator of climatic and hydrological conditions. We conducted an analysis of the interannual variability of the spring mesozooplankton assemblage, as sampled by the PELGAS fisheries survey in the southern part of the Bay of Biscay (Northeast Atlantic Ocean) between 2003 and 2013. We examined hydrology and trophic drivers to explain the variability. Our results revealed that the subsurface temperature, the subsurface salinity, the biomasses of subsurface pico-, nano-, and microphytoplankton, and the copepod assemblage exhibited a recurrent spatial pattern that was driven mainly by freshwater and nutrient inputs from the main rivers. The mesozooplankton assemblage was dominated by copepods (82\%), composed of coastal, neritic, and oceanic copepod genera that paralleled the various hydrological fronts converging in the southern Bay of Biscay. The copepod community displayed high temporal-variability; there were three periods of abundant adult copepods throughout the southern Bay of Biscay. The copepod community was structured primarily around the drive for resource control, especially by the microphytoplankton biomass $(24.3 \%$ of the total variability), and to a lesser extent by hydrological features ( $13.7 \%$ of the total variability).
\end{abstract}




\section{Highlights}

- Spring mesozooplankton was studied over a decade in the southern Bay of Biscay. Hydrobiological features of habitats displayed relatively stable spatial patterns. Spatial structuration of habitats was mainly driven by continental outflow. Mesozooplankton abundance decreased from 2007 to 2009 but recovered afterward. High percentage of gelatinous organisms and low percentage of copepods occurred in 2006. In springtime, the copepod dynamics was mainly governed by resource availability. 


\section{Introduction}

Mesozooplankton $(200-2,000 \mu \mathrm{m})$ play a pivotal role in marine ecosystems by transferring energy from primary producers to the upper trophic levels. They are very sensitive to hydroclimatic features, so climate-mediated changes in zooplankton abundance and composition may affect upper trophic levels and fisheries (Beaugrand, 2003). Zooplankton monitoring therefore represents a powerful tool to detect, understand, and anticipate how global changes induce modifications in pelagic ecosystems (Beaugrand et al., 2003; Beaugrand, 2004; Perry et al., 2004; Richardson, 2008; Hinder et al., 2014). Although extensive and long-term zooplankton surveys have been undertaken (ICES Working Group on Zooplankton Ecology Zooplankton Status Report: http://wgze.net/zooplankton-status-report; 
O'Brien et al., 2013), they still are in relatively short supply compared to fish time-series from commercial catches (Batchelder et al., 2012).

In this study, we investigated the assemblage structure of mesozooplankton (at the level of the species, genus, or family) in the Bay of Biscay, an important Northeast Atlantic fisheries area and a relatively stable ecosystem that primarily is structured around bottom-up forces (e.g., Lassalle et al., 2014). Our investigation covers a large spatio-temporal scale: from the Spanish coast at $46^{\circ} \mathrm{N}$ to the French coast at $3^{\circ} 35^{\prime} \mathrm{W}$, from the spring of 2003 through the spring of 2013. Previous mesozooplankton studies in the Bay of Biscay have been conducted in the spring as well because it is the key period for plankton blooms and the reproductive period for anchovies and sardines (Huret et al., this issue). Although some of these studies considered large spatial and/or temporal scales, they had more limited scopes; some relied on the LOPC (Laser Optical Plankton Counter) technique and were limited to size-structure analyses (Sourisseau and Carlotti, 2006), while others used the CPR (Continuous Plankton Recorder) method and were restricted to the "ultra subsurface" $(0-7 \mathrm{~m})$ (Beaugrand et al. 2000a, 2000b). Studies with high taxonomic resolution focused on a single field survey (Albaina and Irigoien, 2007; Irigoien et al., 2011) or were conducted on limited spatial scales despite their large temporal scales (Albaina and Irigoien, 2007; Stenseth et al., 2006; Valdés and Moral, 1998; Valdés et al., 2007; Gonzalez-Gil et al., 2015; Cabal et al., 2008; Bode et al., 2012 and 2013). Other studies focused on one or two species on a high spatio-temporal scale, such as Bonnet et al. (2005) on Calanus helgolandicus and Lindley and Daykin (2005) on Temora stylifera and Centropages chierchiae. Finally, only two studies were quite similar to ours, conducting large spatio-temporal surveys of the Bay of Biscay, albeit with a lower taxonomic resolution (groups were defined by image analysis) (Irigoien et al. 2009; Vandromme et al. 2014). Irigoien et al. (2009) identified permanent features in the spatial distribution of spring zooplankton between 1998 and 2006, with a higher abundance of large 
organisms over the shelf break and offshore areas. Vandromme et al. (2014) used a combination of LOPC data and WP2 sampling processed with the Zooscan and employed it over the same network of stations used in our study between 2005 and 2012. They found a negative relationship between the zooplankton biomass and normalized biomass size spectra slopes, thus suggesting a clear association between zooplankton size distribution, productivity, and transfer efficiency.

The novelty of the present study lies in the temporal and spatial coverage of the mesozooplankton community structure, with a focus on the main mesozooplankton groups and the key genera or species of copepods. These aspects have not been investigated previously in the Bay of Biscay. From a large data set of annual spring PELGAS ('PELagique GAScogne') surveys (Doray et al., this issue), our study aimed to elucidate which drivers control the spring mesozooplankton community and whether any spatial and/or temporal changes in this community occurred between 2003 and 2013. We had three objectives: 1) to summarize the habitat variabilities in terms of temperature, salinity, and chlorophyll $a$ data; 2) to analyze the temporal patterns of the mesozooplankton and copepod spring communities over the studied decade; and 3) to elucidate which local hydrological and trophic variables may account for the variability of mesozooplankton communities over space and time.

\section{Materials and Methods}

\section{Sampling area}

The Bay of Biscay is characterized by a morphostructural dissymmetry opposing the large northeastern edge of a narrow meridional shelf (Fig. 1). Our study focused on the southern part of the Armorican shelves, which are largely under the influence of the Gironde and the Adour river plumes.

\section{Data collection}


Samples were collected during the annual PELGAS surveys (Doray et al., this volume-b), which have been conducted every spring since 2000 over the whole continental shelf of the Bay of Biscay. In this study, we selected a subset of data with a homogenous mesozooplankton sampling protocol, i.e. data related to the southern part of the Bay of Biscay from 2000-2013 (Fig. 1). PELGAS surveys routinely collect several parameters for all system components, including hydrobiology, pelagic fish abundance and distribution, marine mammals, and seabird observations. We used data that had been collected at night from a total of 118 visited stations (Table 1). Each station was separated from the next by approximately $44 \mathrm{~km}$ in the along-shore direction and $10-25 \mathrm{~km}$ in the cross-shelf direction. PELGAS surveys were not carried out on exactly the same calendar dates over the series (especially at the beginning of the studied decade), although they always did take place during springtime over the course of about 15 days (Table 1).

\section{Hydrology and phytoplankton biomass}

Our station network for hydrology data consisted of 26 to 34 stations per year (Table 1, Fig. 1). At each station, the salinity and temperature were measured over the water column with a CTD (Seabird 19+v2) probe. Two water column integrated indices were calculated: the equivalent freshwater depth $(\mathrm{m})$ and the deficit of potential energy or DEP $\left(\mathrm{kg} \cdot \mathrm{m}^{-1} \cdot \mathrm{s}^{-2}\right)$. As detailed in Huret et al. (2013), the equivalent freshwater depth represents the local depth of freshwater in the absence of mixing. As such, equivalent freshwater depth is a good indicator of the plume influence in a given year and location. The DEP is an index of stratification that is calculated from the vertical distribution of density values.

Chlorophyll $a$-based biomass (chla, see Introduction of Boyer et al. 2009) was used as a proxy of autotrophic biomass (mostly phytoplankton). Water samples (200-500 mL) were collected with Niskin bottles at the subsurface. Once on board, the samples were passed 
through successive filtrations on three membranes with different porosities (Whatman GF/F with pore sizes of $0.7,3$, and $20 \mu \mathrm{m}$ and a diameter of $25 \mathrm{~mm}$ ) to fractionate the samples into three size classes: pico- $(<3 \mu \mathrm{m})$, nano- $(3-20 \mu \mathrm{m})$, and microphytoplankton $(>20 \mu \mathrm{m})$ including large taxa such as diatoms. Each sample was stored at $-20^{\circ} \mathrm{C}$ for subsequent analysis. Laboratory extraction was performed with a Turner TD-700 fluorometer according to the protocols of Aminot and Kérouel (2005) and of Lorenzen (1967). The chla-based biomass was expressed in $\mu \mathrm{g} . \mathrm{L}^{-1}$. An index of water-column integrated chl $a$ biomass $\left(\mu \mathrm{g} . \mathrm{m}^{-2}\right)$ was calculated using the fluorescence data from the vertical profiles (WETStar fluorometer, WET Labs, USA) and corrected by chla-based biomass data.

\section{Mesozooplankton}

The mesozooplankton samples were collected by vertical trawls using WP2 nets $(0.25$ $\mathrm{m}^{2}$ opening, $200 \mu \mathrm{m}$ mesh size), from a depth of $100 \mathrm{~m}$ (or the bottom depth for inshore stations). For each annual survey, ten or 12 stations were selected from four transects; this sampling included coastal, continental shelf, and slope stations (Fig. 1B). After collection, the net samples were preserved in $4 \%$ formaldehyde. The organisms were identified by species, genus, family, or more general categories/forms (Table 2; identification protocol of Rose (1933) and Tregoubof and Rose (1957)), and were enumerated using a Leica M3Z stereo microscope $\left(65 \times\right.$ to $100 \times$ magnification). The abundance was expressed in individuals $\mathrm{m}^{-3}$ (ind. $\mathrm{m}^{-3}$ ).

\section{Data analysis \\ Ordinary kriging}

To describe the spatio-temporal patterns of the different studied compartments, an ordinary kriging procedure (ArcMap 10.2 using the Geostatistical Analyst toolbox) was 
applied to the data for the subsurface temperature, salinity, and size-fractionated chla-based biomass. For each parameter, annual data were compiled from 2003-2013 and interpolated to provide an overview of the spring spatial patterns over the time series. For each parameter, annual kriged maps are presented in Supplemental Figures 1-4. To identify significant temporal variations (i.e., across years) for each parameter (temperature, salinity, and pico-, nano-, and microphytoplankton biomasses), a non-parametric multiple pairwise comparison (Statistica ${ }^{\circledR}$, Tulsa, OK, USA) of mean ranks was applied to all years from 2003-2013; pvalues $<0.05$ were considered significant. All other statistical analyses were performed with the R-Cran project free software (R Core Team, 2014). Furthermore, to consider these five water mass variables together throughout the decade, confidence ellipses (surrounding the barycentre of coordinate stations) were determined on a station factor map produced by a principal component analysis (PCA, 'FactoMineR' package (Husson et al., 2012)).

\section{Mesozooplankton community analysis}

The time-variability of the mesozooplankton community was analyzed by considering the mean yearly relative abundance of classical characteristic groups of mesozooplankton (meroplankton, gelatinous plankton, copepods, and other holoplankton). The abundance and taxonomic composition of the dominant group (copepods) was analyzed according to the variability in space and over time. As done in previous studies, a temporal analysis was conducted via a multiple comparison of the mean ranks for all years based on copepod abundance. The spatio-temporal variation in the composition of the adult copepod community was also described with a non-metric multi-dimensional scaling (NMDS), performed using Primer 6 (Plymouth Routines In Multivariate Ecological Research) software. A matrix of sampling points ( $\mathrm{n}=118$ samples; see Table 1) was created for the abundance data of copepods species or genera $(n=23)$. In this matrix, the columns corresponded to the copepod taxa 
abundances, and the lines to the sampling points. The data were transformed with $\log x+1$ before the Bray-Curtis metric was applied to estimate the similarity between stations. The similarity matrix was then ordinated by NMDS. A SIMPER (SIMilarity PERcentage) analysis was performed to identify the genera or species contributing most to similarity (or dissimilarity) within (or between) three groups of sampling years defined from the time series analysis.

Finally, to quantify the relative influences of the food-resource $(\operatorname{chl} l a)$ and abiotic parameters (temperature, salinity) explaining the patterns observed in the copepod community, a variation partitioning analysis (using "vegan" and "ade4" packages in the R-Cran project free software) was applied (Volis et al., 2011). We considered biotic variables (subsurface and integrated water column values of chla for pico-, nano-, and microphytoplankton fractions) and abiotic variables (subsurface values of temperature and salinity, and three water column integrated indices; the DEP, the equivalent freshwater, and the mixed-layer depth). First the variables to include in the analysis (i.e. variables that influenced the most the copepod distribution) were selected through forward selection ("packfor" package). Two matrices were built from this selection, $\mathrm{H}$ for abiotic parameters, and $\mathrm{C}$ for biotic parameters. Finally, using these two matrices, the variation partitioning was performed in order to identify the part of the variation in copepod distribution explained by hydrological parameters or phytoplankton resources.. Indeed, Variation partitioning evaluates diverse components of variation: 1) the pure effect of each individual matrix, 2) the redundancy of the two explanatory matrices through interactions, and 3) the residual effects that are unexplained by the chosen variables. Redundancy analysis (RDA) was performed for the overall variation analysis, partial redundancy analysis (pRDA) for the individual matrix effects, and Monte Carlo permutation (999 permutations) tests were used to test the significance of the canonical axis. 


\section{Results}

\section{Subsurface salinity and temperature}

The absence of a spatial pattern in the decadal average map (Fig. 2) means that no spring-time mesoscale process had a strong recurrent impact on the surface temperature in the southern Bay of Biscay. However, a coast-to-offshore positive gradient can be observed in certain years (e.g., in 2006, 2010, and 2013; see Fig. S1), revealing the intermittent occurrence of an upwelling process along the southern French coast. The Gironde plume brought characteristically lower temperatures in 2005 and 2006, and a latitudinal gradient also appeared in some years (e.g., in 2010, 2012, and 2013), albeit without any consistent pattern across years. These anomalies may be explained by the changing meteorological conditions (e.g., wind, irradiance) during the 15-day survey conduction. During the studied decade (2003-2013), the subsurface temperature varied from $10.8^{\circ} \mathrm{C}$ to $19.8^{\circ} \mathrm{C}$, highlighting the large interannual variability in the surface warming and the stratification process during this rapidly changing season. The non-parametric multiple pairwise comparison allowed for a separation of the years into three groups: 2003 was the warmest, 2007 and 2011 had intermediate temperatures, and the remaining years were the coldest (see Fig. S1).

The spatial pattern of salinity was driven by the plumes of the Gironde and the Adour rivers (Fig.2). Despite some interannual variability in the extension of the plumes (maxima in 2007, 2009, and 2013; minima in 2011 and 2012), the interannual variability of the subsurface salinity was not significantly different between years (multiple pairwise comparison, $\mathrm{p}=0.05$ ) (see Fig. S2). Subsurface salinities varied from 26.07 psu to 36.4 psu (see Fig. S2).

\section{Chlorophyll $a$-based biomasses}

The average picture of the chla biomasses (Fig.2) revealed a homogeneous concentration over the shelf, with lower values off-shelf, for the two smallest size classes $(<3$ 
$\mu \mathrm{m}$ and 3-20 $\mu \mathrm{m})$. For the largest size class $(>20 \mu \mathrm{m})$, the highest values were found over a coastal strip only. Generally, biomasses were higher in the area influenced by the Gironde plume as compared to the most other southern locations.

Substantial differences appeared when analyzing the annual maps of chla biomasses (see Figs. S3, S4, and S5). For the smallest size class (Fig. S3), significant interannual differences allowed the years to be divided into five groups: 2003 exhibited the lowest values $\left(0.20 \pm 0.38 \mu \mathrm{g} . \mathrm{L}^{-1}\right)$ and $2009-2010$ exhibited the highest $\left(0.66 \pm 0.41 \mu \mathrm{g} . \mathrm{L}^{-1}\right)$. For the 3-20 $\mu \mathrm{m}$ size class, the interannual variability revealed four groups of years, with mean biomasses ranging from $0.17 \pm 0.26 \mu \mathrm{g} . \mathrm{L}^{-1}$ to $0.45 \pm 0.37 \mu \mathrm{g} . \mathrm{L}^{-1}$. For the $>20 \mu \mathrm{m}$ size class, no significant interannual differences were found between years.

The non-parametric multiple pairwise comparison of the five environmental variables (subsurface salinity and temperature, subsurface pico-, nano-, and microphytoplankton biomasses) over the decade could not extract significant differences between years.

The average contribution of each size class over the studied decade (Fig. 3) was $44 \%$ for picophytoplankton $(<3 \mu \mathrm{m}), 23 \%$ for nanophytoplankton $(3-20 \mu \mathrm{m})$, and $33 \%$ for microphytoplankton (> $20 \mu \mathrm{m}$ ) (Fig. 3). The relative contributions varied from 23\% (2003) to $67 \%$ (2009) for the picophytoplankton, from $19 \%$ (2008) to $42 \%$ (2003) for the nanophytoplankton, and from $10 \%$ (2007) to $42 \%$ (2008) for the microphytoplankton (including larger taxa such as diatoms).

\section{Mesozooplankton}

Total abundance and the contribution of the main groups

The mean spring abundance of mesozooplanktonic organisms over the study period varied from $1,321 \pm 391$ ind. $\mathrm{m}^{-3}$ (2008) to 4,986 \pm 355 ind. $\mathrm{m}^{-3}$ (2005) (Fig. 4A). Between 2003 and 2006, abundances were higher $\left(4,454,3,233,4,985\right.$, and 4,191 ind. $\mathrm{m}^{-3}$ for each year, 
respectively) than the mean decadal value $\left(2,995 \pm 1,195\right.$ ind. $\left.\mathrm{m}^{-3}\right)$, while the mean abundances were lower than the mean decadal value between 2007 and 2013, with the exceptions of 2010 and 2012 (with 3,349 and 3,061 ind.m ${ }^{-3}$, respectively). The spring abundance of mesozooplanktonic organisms revealed three temporal phases: from 2003-2006 (higher than the mean decadal value), from 2007-2009 (lower than the mean decadal value), and from 2010-2013 (close to the mean decadal value, except 2011, which was below the mean decadal value). The lowest contribution of copepods was registered in 2006 (Fig. 4B). The gelatinous organisms encountered in 2006 were mainly cnidaria and siphonophora as well as major meroplankton organisms (Bivalvia larvae and Cirripedia). On average, more than $80 \%$ of the spring mesozooplankton community comprised copepods, $8 \%$ meroplankton, $8 \%$ gelatinous plankton, and 4\% other holoplanktonic organisms (Fig. 4B). Depending on the year, the relative abundance of copepods varied from 42\% (2006) to 87\% (both 2011 and 2009), those of meroplankton from $1 \%$ (2009) to $22 \%$ (2006), those of gelatinous organisms from $3 \%$ (2011) to $24 \%$ (2006), and those of the other holoplanktonic organisms from $2 \%$ (2009) to $11 \%$ (2010). Meroplanktonic organisms were found mostly along the coast, gelatinous organisms were scattered, and the other holoplanktonic organisms were widespread among the sampling stations (data not shown). Based on these observations, the following results focus on the main group: the copepods.

\section{Copepod patterns}

Over the 11 springtime surveys, copepodites (16\% of the total copepod abundance) and nauplii (1.4\%) of miscellaneous copepod species were recorded.

Twenty-five adult copepod taxa (at the family, genus, or species level) were recorded; orders included Harpacticoida, Poecilostomatoida, Cyclopoida, and Calanoida, as well as copepodites and copepod nauplii (Table 2). The spatial distribution of these 25 taxa is shown 
in Fig. 5. Irrespective of the year, the copepod abundance followed a longitudinal gradient: coastal waters had the highest values $\left(2,848 \pm 2,507\right.$ ind. $\left.\mathrm{m}^{-3}\right)$, shelf waters had intermediate values $\left(2,335 \pm 3,787\right.$ ind. $\left.\mathrm{m}^{-3}\right)$, and the continental slope had the lowest values $(1,304 \pm 1,546$ ind. $\left.\mathrm{m}^{-3}\right)$, except for in $2010\left(1,467\right.$ ind. $\left.\mathrm{m}^{-3}\right)$. One outlier of copepod abundance $\left(21,127\right.$ ind. $\mathrm{m}^{-}$ ${ }^{3}$ ) was recorded in 2005 at a single station on the northern coast. From a temporal viewpoint and based on the annual abundances at each station, only 2009 could be distinguished from the other years (Fig. S6). Moreover, eight of these 25 adult taxa (Oithona spp., Acartia spp., Temora longicornis, Oncaea spp., Calanidae, Calanus helgolandicus, Paracalanidae, and Euterpina acutifrons) alone represented more than $1.5 \%$ of the copepod abundance (Table 2). Their spring spatial abundances in the Bay of Biscay are plotted in Fig. 5. Oithona spp. was present preferentially from the continental shelf to the slope; Acartia spp., Oncaea spp., and Temora longicornis were most common at the coastal stations; and the genera Acartia, Oithona, Temora, and Oncaea were the most abundant within the copepod community (66\% between 2003 and 2013; see details in Table 2).

\section{Spatio-temporal variations of adult copepods}

The NMDS ordination of the adult copepod abundance data (stress value of 0.23 , indicating a good ordination) discriminated the temporal variations better than the spatial variations. The plots of the three time-sampling groups previously discerned by the temporal analysis of abundance (see above) showed that the adult copepod community in the 20032006 period was clearly distinct from the $2007-2009$ period (Fig. 6). The last period (20102013) was intermediate, suggesting a return toward the initial situation (2003-2006) (Fig. 6). The SIMPER analysis (Tables 3 and 4) confirmed this trend, with the same four taxa (Oithona spp., Oncaea spp., Acartia spp., and Temora longicornis) explaining > 65\% of the similarity within the 2003-2006 and 2010-2013 periods, whereas in 2007-2009, Paracalanidae (15\% 
contribution for this group) replaced Temora longicornis (7.8\%) in these top-four taxa. Overall, the within-group similarity was higher for the 2003-2006 (67.0\%) and the 2010$2013(59.9 \%)$ periods than for the 2007-2009 period (52.3\%). The level of dissimilarity between the groups was highest between 2003-2006 and 2007-2009 (52.0\%), and lowest between 2003-2006 and 2010-2013 (45.5\%).

\section{Hydrological versus trophic control on the spring copepod community}

The forward selection identified four significant variables that significantly drive the copepod community:: microphytoplankton (> $20 \mu \mathrm{m}$ ) biomass at the subsurface, equivalent freshwater height, DEP, and subsurface temperature (Table 5). The variation partitioning highlighted that $49.2 \%$ of the variation was explained by both matrices $\mathrm{H}$ and $\mathrm{C}$ with the most variance (24.3\%) attributable to chla-based microphytoplankton biomass and the next-most variance (13.7\%) attributable to hydrological parameters (Figure 7, Supplemental table 1). The part of the variation due by the interaction between the two matrices (ie. between hydrological parameters and subsurface microphytoplankton) was $11.2 \%$. Partial RDA (without interaction between variables) concurred that the distribution of the copepod community was influenced significantly by the microphytoplankton subsurface biomass, equivalent freshwater height, and DEP (Supplemental table 1). The contribution of the subsurface temperature was not significant in the variation partitioning analysis.

\section{Discussion}

Hydrological and biological features of the mesozooplankton habitat

Throughout the 2003-2013 decade, surface water warming occurred continually in the Bay of Biscay, from the south to the north and from the coast to the open sea. The water mass circulation in the Bay of Biscay is drived by a combination of large-scale and local forces (Le 
Boyer et al., 2013); the warming of water masses in spring is modulated by slope currents, shelf residual circulation, and the Iberian Poleward Current from Galicia to the Bay of Biscay on a larger scale, and wind and irradiance conditions on a local scale (Koutsikopoulos and Le Cann, 1996; Puillat et al., 2004; Rubio et al., 2013). From our study, the spatial pattern of variability in the south of the Bay appeared to be independent of the interannual variability of the hydrobiological parameters (e.g., the subsurface temperature). From 2003-2013, the survey observed a mix of warm (in 2003, 2007, and 2011), intermediate, and cold years. This variation in temperature regimes is consistent with results previously reported in this area (e.g., Huret et al., 2013).

The size structure of the phytoplankton community contribute to the structure of pelagic food webs, so our study considered three size classes (pico-, nano-, and microphytoplankton). Indeed, mesozooplanktonic organisms are major grazers of nano- and microphytoplankton (Marquis et al., 2007). Calvo-Díaz et al. (2008) recorded the monthly contributions (in Iberian Peninsula waters from 2003-2006) of each size fraction of phytoplankton, and showed that the spring (i.e., April) contribution of picophytoplankton was about $20 \%$, corresponding to the minimum recorded over an annual cycle. By contrast, the contributions of nanophytoplankton and microphytoplankton were around $50 \%$ and $30 \%$, respectively. In our study, the mean balance between pico- and nanophytoplankton varied widely, most likely because our spatial coverage involved more oceanic features beyond $200 \mathrm{~m}$ of bathymetry. It is important to note that the survey dates were not exactly the same throughout the decade and hence added further variability. For example, compared to the later surveys, the 2003 survey captured significantly different hydrology, plankton concentration, and size structure.

To summarize, taking into account both the hydrological and the phytoplanktonic components of the mesozooplankton habitat, the Bay of Biscay appeared to support a 
consistent spatial structure across years, due mainly to the continental supply of freshwater and nutrients, although a degree of interannual variability occurred in the range of the observed values.

\section{The spring mesozooplankton community}

Among the prominent groups of the mesozooplankton community, meroplanktonic organisms were restricted to the coastal area in our study, as previously reported by Ayata et al. (2011). By contrast, gelatinous organisms were dispersed throughout the Bay of Biscay. No clear spatio-temporal development of gelatinous plankton was observed, although this group (mainly cnidaria and siphonophora) was particularly abundant in 2006. Their proliferation may be linked to climate change, eutrophication, and/or habitat modifications (e.g., Lo et al., 2008). However, the WP2 net used in the study probably was not the most suitable device for monitoring gelatinous plankton.

In the present study, copepods represented the most dominant holoplankton taxa of the mesozooplankton community, as highlighted by various studies in the same area (e.g., Albaina and Irigoien, 2007; Irigoien et al., 2009; Valdés et al., 2007; Villate et al., 2014, 1997). Previous observations of the spatial distribution of the spring size structure of mesozooplankton have reported a negative coastal-to-offshore gradient (e.g., Vandromme et al., 2014), as also observed in the present study for copepod taxa. Here, the sample represented three dominant genera and one dominant species $(>10 \%$ of the copepod abundance) Acartia spp., Oncaea spp., Oithona spp., and Temora longicornis-consistent with previous investigations (e.g., Albaina and Irigoien, 2007; Irigoien et al., 2011). According to the literature regarding the copepod community in the Bay of Biscay, Temora longicornis and Pseudocalanus elongatus are dominant neritic species that occur preferentially on the continental shelf, whereas Acartia spp. dominates stations under coastal 
influence, and Calanus helgolandicus and Eucalanidae dominate under oceanic influence. More specifically, C. helgolandicus is found in the southern part of the Bay of Biscay and in the surface layers in the north during the spring (Bonnet et al. 2005).

\section{Temporal trends in the mesozooplankton and copepod communities}

Climatic indicators increasingly are being explored to identify major changes affecting plankton (e.g.,Wouters et al., 2015) and fish communities (Guénette and Gascuel, 2012). On a similar spatial scale as in the present study, previous research detected oscillations mainly in the vicinity of the Gironde river plume, which represents a major source of nutrient inputs into the Bay of Biscay for both plankton (David et al., 2005) and fish (Pasquaud et al., 2012). Overall temperatures in the Gironde estuary increased significantly around 1987 and again around 2001 (Chaalali et al., 2013).

During the decade studied here, the year 2005 brought additional abrupt changes in mesozooplankton abundance and diversity in the Gironde estuary-a relatively closed system - and in the Arcachon basin (Chaalali, personal communication). It is possible that this abrupt change also occurred in the Bay of Biscay, albeit with a time lag that is linked to the Bay's resilience properties. As described above, three temporal phases of adult copepod dominance were observed in the present study: 2003-2006, 2007-2009, and 2010-2013, with abundance values that were higher, lower, and higher, respectively, than the spring mean decadal abundance (including 2003-2013). This temporal oscillation also correlated with taxonomic composition changes (see Tables 3 and 4). However, we observed that 2010-2013 witnessed a reversal to the initial situation (2003-2006) with regard to both the abundance and taxonomic composition of the adult copepod community. The only anomaly detected was the high percentage of gelatinous organisms in the spring of 2006, which correlated with the low percentage of copepods observed that year. These gelatinous organisms comprised 
cnidaria and siphonophora primarily. It is reasonable to consider predation as a possible cause, as this would result in top-down control on copepods and spatial occupation of a very close ecological niche between carnivorous copepods, cnidarian, and siphonophora organisms.

\section{Factors controlling the spring copepod community}

The structure and functioning of planktonic food webs depend largely on the hydrodynamics of the water column. Our study found that four variables of the pelagic habitat (subsurface temperature, stratification with the deficit of potential energy, equivalent freshwater height, and subsurface microphytoplankton biomass) accounted for more than $49 \%$ of the variability in the main mesozooplanktonic community. Zarauz et al. (2008) suggested that the mesozooplankton biomass is driven mainly by hydrogeographic data (e.g., latitude, longitude, surface temperature, salinity, stratification index, and water depth), and to a lesser extent by potential trophic resources (e.g., the nano-microplankton biomass). By contrast, the present study showed that for the same study site (same scale and season), the spring copepod community (described taxonomically) was influenced more by trophic variables (e.g., microphytoplankton biomass; $24.3 \%$ of the total variability) than by hydrographic variables (13.7\% of the total variability) over the 11-year time period. These differences can be explained by the fact that Zarauz et al. (2008) studied mesozooplankton at the biomass level only, whereas our study took into account the abundance of taxa (species, gender, or family) to describe the community. These methods do not provide the same ecological information. Moreover, the temporal dataset was not exactly the same: Zarauz et al. (2008) studied three spring seasons (2004-2006) while the present study included eleven spring seasons (20032013). Finally, the two studies used different trophic variables for the statistical analysis: 
nano-microplankton biomass in Zarauz et al. (2008) vs. phytoplankton biomasses by size classes in the present study.

At the scale and with the spring timing of our study, the trophic link (i.e., the subsurface microphytoplankton biomass) appeared to be the major driver of the copepod community, while hydrographic variables appeared to play less important roles. There are two potential reasons for this: i) the trophic dimension probably represents a time integration of hydrological conditions (i.e., more integrated than the temperature and salinity variables in the present context), and ii) the planktonic food web probably has an ecological succession of physical and geographical parameters that control the initial phytoplanktonic blooms in late winter. Nutrients then become limited in spring, ultimately influencing the production and life cycle of mesozooplankton, which thus are maintained by trophic control during the PELGAS spring surveys. However, copepods have other potential trophic sources, such as ciliates and heterotrophic flagellates, that can influence the mesozooplankton distribution but were not considered in our study.

According to the present observations, both the thermal stratification and equivalent freshwater height significantly affected the copepod community, whereas subsurface salinity did not. This probably is because thermal stratification and equivalent freshwater height are more integrated spatially and temporally. However, it is surprising the water column integrated chla index did not have a prominent effect in the non-parametric multiple pairwise comparison of mean ranks. Thus, an approach using functional traits appears to be more efficient for understanding the springtime copepod community, as copepods are major predators of microphytoplankton (Marquis et al., 2007). Moreover, although fewer stations were sampled in our study than in Irigoien et al. (2011), we explained a greater percentage of the community's variability, probably because our data set spanned a longer period of time and therefore captured more variability. However, half of the variation in the copepod 
community over the studied decade remained unexplained. We concur with Irigoien et al. (2011) that other biological functional traits of the present community-including the effect of copepod density on feeding activities — merit consideration.

\section{Concluding remarks}

This study of annual springtime PELGAS survey data is the only analysis of the southern Bay of Biscay's mesozooplankton community between 2003 and 2013. We claim the following contributions:

- We demonstrated that the spatial structure found in the Bay of Biscay is attributable to continental outflow, although some interannual variability occurred in the range of the values observed.

- We generated interpolation maps that represent a valuable foundation for future studies in the Bay of Biscay.

- We identified three time-oscillation phases (in terms of both abundance and taxonomic composition) in the mesozooplankton community, with a major change recorded in 2006.

- We demonstrated, for the first time in this area, the influence of trophic variables (i.e., microphytoplankton biomass) from 2003-2013.

\section{Acknowledgments}

We thank the entire PELGAS team - researchers, technicians, students, captains and crews of R/V "Thalassa" - who have contributed to the collection of the PELGAS samples since 2003. We would like to express our thanks to two teams' laboratory, LIENSs and EMH and especially, M. Jacques, P. Petitgas, M. Doray, and P. Bourriau. We are grateful to Proofreading and Dr. Sophie Domingues-Montanari for English corrections. We also grateful to 
Céline Lavergne for its statistical advices. The IUF (Institut Universitaire de France) is acknowledged for its support to PB as a Senior Member. This research was supported through a $\mathrm{PhD}$ grant for A. Dessier from the Conseil Régional de Poitou-Charentes and by the European project REPRODUCE (EraNet-Marifish, FP7). This work was supported by the "Plateau Microscopie" of the LIENSs laboratory.

\section{References}

Albaina, A., Irigoien, X., 2007. Fine scale zooplankton distribution in the Bay of Biscay in spring 2004. J. Plankton Res. 29, 851-870. doi:10.1093/plankt/fbm064

Aminot, A., Kérouel, R., 2005. Hydrologie des écosystèmes marins. Paramètres et analyses., Ifremer. ed, Méthodes d'analyses du milieu marin.

Ayata, S.-D., Stolba, R., Comtet, T., Thiébaut, É., 2011. Meroplankton distribution and its relationship to coastal mesoscale hydrological structure in the northern Bay of Biscay (NE Atlantic). J. Plankton Res. 33, 1193-1211. doi:10.1093/plankt/fbr030

Batchelder, H.P., Mackas, D.L., O’Brien, T.D., 2012. Spatial-temporal scales of synchrony in marine zooplankton biomass and abundance patterns: A world-wide comparison. Glob. Comp. Zooplankton Time Ser. 97-100, 15-30. doi:10.1016/j.pocean.2011.11.010

Beaugrand, G., Brander, K.M., Lindley, J.A., Souissi, S., Reid, P.C., 2003. Plankton effect on cod recruitment in the North Sea. Nature 426, 661-664. doi:10.1038/nature02164

Beaugrand, G., Ibañez, F., Lindley, J.A., Reid, P.C., 2002. Diversity of calanoid copepods in the North Atlantic and adjacent seas: Species associations and biogeography. Mar. Ecol. Prog. Ser. 232, 179-195. doi:10.3354/meps232179

Beaugrand, G., Ibanez, F., Reid, P.C., 2000a. Spatial, seasonal and long-term fluctuations of plankton in relation to hydroclimatic features in the English Channel, Celtic Sea and Bay of Biscay. Mar. Ecol. Prog. Ser. 200, 93-102.

Beaugrand, G., Reid, P.C., Ibañez, F., Planque, B., 2000b. Biodiversity of North Atlantic and North Sea calanoid copepods. Mar. Ecol. Prog. Ser. 204, 299-303.

Bode, A., Alvarez-Ossorio, M., Miranda, A., López-Urrutia, A., Valdés, L., 2012. Comparing copepod time-series in the north of Spain: Spatial autocorrelation of community composition. Prog. Oceanogr. 97-100, 108-119. doi:10.1016/j.pocean.2011.11.013

Bode, A., Álvarez-Ossorio, M.T., Miranda, A., Ruiz-Villarreal, M., 2013. Shifts between gelatinous and crustacean plankton in a coastal upwelling region. ICES J. Mar. Sci. 70, 934942. doi:10.1093/icesjms/fss 193

Bonnet, D., Richardson, A., Harris, R., Hirst, A., Beaugrand, G., Edwards, M., 2005. An overview of Calanus helgolandicus ecology in European waters. Prog. Oceanogr. 65, 1-53. doi:10.1016/j.pocean.2005.02.002

Boyer, J.N., Kelble, C.R., Ortner, P.B., Rudnick, D.T., 2009. Phytoplankton bloom status: Chlorophyll a biomass as an indicator of water quality condition in the southern estuaries of Florida, USA. Ecol. Indic. 9, S56-S67. doi:10.1016/j.ecolind.2008.11.013

Cabal, J., González-Nuevo, G., Nogueira, E., 2008. Mesozooplankton species distribution in the NW and N Iberian shelf during spring 2004: Relationship with frontal structures. J. Mar. Syst. 72, 282-297. doi:10.1016/j.jmarsys.2007.05.013 
Calvo-Díaz, A., Morán, X.A.G., Suárez, L.Á., 2008. Seasonality of picophytoplankton chlorophyll a and biomass in the central Cantabrian Sea, southern Bay of Biscay. J. Mar. Syst. 72, 271-281. doi:10.1016/j.jmarsys.2007.03.008

Chaalali, A., Beaugrand, G., Boët, P., Sautour, B., 2013. Climate-Caused Abrupt Shifts in a European Macrotidal Estuary. Estuaries Coasts 36, 1193-1205. doi:10.1007/s12237-0139628-x

Childs, C., 2004. Interpolating Surfaces in ArcGIS Spatal Analyst - interpolating.pdf. ESRI Educ. Serv. ArcUser.

Doray Mathieu, Petitgas Pierre, Huret Martin, Duhamel Erwan, Romagnan Jean-Baptiste, Authier Matthieu, Dupuy Christine, Spitz Jerome. this volume-a. Monitoring small pelagic fish in the Bay of Biscay ecosystem, using indicators from an integrated survey . Progress in Oceanography IN PRESS . http://doi.org/10.1016/j.pocean.2017.12.004

Doray, M., Petitgas, P., Romagnan, J.B., Huret, M., Duhamel, E., Dupuy, C., Spitz, J., Authier, M., Sanchez, F., Berger, L., Dorémus, G., Bourriau, P., Grellier, P., Massé, J., this volume-b. The PELGAS survey: ship-based integrated monitoring of the Bay of Biscay pelagic ecosystem. Prog. Oceanogr.

González, M., Fontán, A., Esnaola, G., Collins, M., 2013. Abrupt changes, multidecadal variability and long-term trends in sea surface temperature and sea level datasets within the southeastern Bay of Biscay. XII Int. Symp. Oceanogr. Bay Biscay 109-110, Supplement, S144-S152. doi:10.1016/j.jmarsys.2011.11.014

Guénette, S., Gascuel, D., 2012. Shifting baselines in European fisheries: The case of the Celtic Sea and Bay of Biscay. Spec. Issue Fish. Policy Reform EU 70, 10-21. doi:10.1016/j.ocecoaman.2012.06.010

Hinder, S.L., Gravenor, M.B., Edwards, M., Ostle, C., Bodger, O.G., Lee, P.L.M., Walne, A.W., Hays, G.C., 2014. Multi-decadal range changes vs. thermal adaptation for north east Atlantic oceanic copepods in the face of climate change. Glob. Change Biol. 20, 140-146. doi:10.1111/gcb.12387

Huret, M., Sourisseau, M., Petitgas, P., Struski, C., Léger, F., Lazure, P., 2013. A multidecadal hindcast of a physical-biogeochemical model and derived oceanographic indices in the Bay of Biscay. XII Int. Symp. Oceanogr. Bay Biscay 109-110, Supplement, S77-S94. doi:10.1016/j.jmarsys.2012.02.009

Huret M, Bourriau P, Doray M, Gohin F, Petitgas P (2018) Survey timing vs. ecosystem scheduling: Degree-days to underpin observed interannual variability in marine ecosystems. Prog Oceanogr, In Press.

Husson, F., Josse, J., Le, S. \& Mazet, J. (2012) FactoMineR: Multivariate Exploratory Data Analysis and Data Mining with R. R package version 1.18.

Irigoien, X., Chust, G., Fernandes, J.A., Albaina, A., Zarauz, L., 2011. Factors determining the distribution and betadiversity of mesozooplankton species in shelf and coastal waters of the Bay of Biscay. J. Plankton Res. 33, 1182-1192. doi:10.1093/plankt/fbr026

Irigoien, X., Fernandes, J.A., Grosjean, P., Denis, K., Albaina, A., Santos, M., 2009. Spring zooplankton distribution in the Bay of Biscay from 1998 to 2006 in relation with anchovy recruitment. J. Plankton Res. 31, 1-17. doi:10.1093/plankt/fbn096

Koutsikopoulos, C., Le Cann, B., 1996. Physical processes and hydrological structures related to the Bay of Biscay anchovy. Sci. Mar. 60, 9-19.

Lassalle, G., Chouvelon, T., Bustamante, P., Niquil, N., 2014. An assessment of the trophic structure of the Bay of Biscay continental shelf food web: Comparing estimates derived from an ecosystem model and isotopic data. Prog. Oceanogr. 120, 205-215. doi:10.1016/j.pocean.2013.09.002 
Le Boyer, A., Charria, G., Le Cann, B., Lazure, P., Marié, L., 2013. Circulation on the shelf and the upper slope of the Bay of Biscay. Cont. Shelf Res. 55, 97-107. doi:10.1016/j.csr.2013.01.006

Legendre, L., Le Fèvre, J., 1991. From Individual Plankton Cells To Pelagic Marine Ecosystems And To Global Biogeochemical Cycles, in: Demers, S. (Ed.), Particle Analysis in Oceanography, NATO ASI Series. Springer Berlin Heidelberg, pp. 261-300.

Lindley, J.A., Daykin, S., 2005. Variations in the distributions of Centropages chierchiae and Temora stylifera (Copepoda: Calanoida) in the north-eastern Atlantic Ocean and western European shelf waters. ICES J. Mar. Sci. 62, 869-877. doi:10.1016/j.icesjms.2005.02.009

Lo, W.-T., Purcell, J.E., Hung, J.-J., Su, H.-M., Hsu, P.-K., 2008. Enhancement of jellyfish (Aurelia aurita) populations by extensive aquaculture rafts in a coastal lagoon in Taiwan. Ices J. Mar. Sci. 65, 453-461. doi:10.1093/icesjms/fsm185

Lorenzen, C.J., 1967. Determination of chlorophyll and pheopigments: spectrophotometric equations. Limnol. Oceanogr. 12, 343-346.

Marquis, E., Niquil, N., Delmas, D., Hartmann, H.J., Bonnet, D., Carlotti, F., Herbland, A., Labry, C., Sautour, B., Laborde, P., Vézina, A., Dupuy, C., 2007. Inverse analysis of the planktonic food web dynamics related to phytoplankton bloom development on the continental shelf of the Bay of Biscay, French coast. Estuar. Coast. Shelf Sci. 73, 223-235. doi:10.1016/j.ecss.2007.01.003

Motos, L., 1996. Reproductive biology and fecundity of the Bay of Biscay anchovy population (Engraulis encrasicolus L.). Sci. Mar. 60, 195-207.

O’Brien, T.D., Wiebe, P.H., Falkenhaug, T., 2013. ICES Zooplankton Status Report 2010/2011 (No. 318). ICES Cooperative Research Report.

Pasquaud, S., Béguer, M., Larsen, M.H., Chaalali, A., Cabral, H., Lobry, J., 2012. Increase of marine juvenile fish abundances in the middle Gironde estuary related to warmer and more saline waters, due to global changes. Estuar. Coast. Shelf Sci. doi:10.1016/j.ecss.2012.03.021

Perry, R.I., Batchelder, H.P., Mackas, D.L., Chiba, S., Durbin, E., Greve, W., Verheye, H.M.,2004. Identifying global synchronies in marine zooplankton populations: Issues and opportunities. ICES J. Mar. Sci. 61, 445-456. doi:10.1016/j.icesjms.2004.03.022

Planque, B., Bellier, E., Jégou, A.M., Lazure, P., Puillat, I., 2003. Large scale hydroclimatic variability in the Bay of Biscay. The 1990s in the context of interdecadal changes. ICES Mar. Sci. Symp. 219, 61-70.

Puillat, I., Lazure, P., Jégou, A.., Lampert, L., Miller, P.., 2004. Hydrographical variability on the French continental shelf in the Bay of Biscay, during the 1990s. Cont. Shelf Res. 24, 1143-1163. doi:10.1016/j.csr.2004.02.008

Puillat, I., Lazure, P., Jégou, A., Planque, B., Lampert, L., 2003. Mesoscale, interannual, and Seasonal hydrological variability over the French continental shelf of the Bay of Biscay during the 1990s. ICES Mar. Sci. Symp. 219, 333-336.

R Core Team, 2014. R: A language and environment for statistical computing. R Found. Stat. Comput. Vienna Austria.

Richardson, A.J., 2008. In hot water: zooplankton and climate change. ICES J. Mar. Sci. J. Cons. 65, 279-295. doi:10.1093/icesjms/fsn028

Rose, M., 1933. Faune de France - Copépodes Pélagiques, Fédération française des sociétés des sciences naturelles - Office central de Faunistique.

Rubio, A., Fontán, A., Lazure, P., González, M., Valencia, V., Ferrer, L., Mader, J., Hernández, C., 2013. Seasonal to tidal variability of currents and temperature in waters of the continental slope, southeastern Bay of Biscay. XII Int. Symp. Oceanogr. Bay Biscay 109-110, Supplement, S121-S133. doi:10.1016/j.jmarsys.2012.01.004 
Sourisseau, M., Carlotti, F., 2006. Spatial distribution of zooplankton size spectra on the French continental shelf of the Bay of Biscay during spring 2000 and 2001. J. Geophys. Res. Oceans 111, 12. doi:10.1029/2005JC003063

Stenseth, N.C., Llope, M., Anadon, R., Ciannelli, L., Chan, K.-S., Hjermann, D.O., Bagoien, E., Ottersen, G., 2006. Seasonal plankton dynamics along a cross-shelf gradient. Proc. R. Soc. B Biol. Sci. 273, 2831-2838. doi:10.1098/rspb.2006.3658

Tregoubof, G., Rose, M., 1957. Le manuel de planctonologie méditerranéenne, Centre National de la Recherche Scientifique. Paris.

Valdés, L., López-Urrutia, A., Cabal, J., Alvarez-Ossorio, M., Bode, A., Miranda, A., Cabanas, M., Huskin, I., Anadón, R., Alvarez-Marqués, F., 2007. A decade of sampling in the Bay of Biscay: What are the zooplankton time series telling us? Prog. Oceanogr. 74, 98-114. doi:10.1016/j.pocean.2007.04.016

Valdés, L., Moral, M., 1998. Time-series analysis of copepod diversity and species richness in the southern Bay of Biscay off Santander, Spain, in relation to environmental conditions. ICES J. Mar. Sci. J. Cons. 55, 783-792. doi:10.1006/jmsc.1998.0386

Vandromme, P., Nogueira, E., Huret, M., Lopez-Urrutia, Á., González-Nuevo González, G., Sourisseau, M., Petitgas, P., 2014. Springtime zooplankton size structure over the continental shelf of the Bay of Biscay. Ocean Sci. 10, 821-835. doi:10.5194/os-10-821-2014

Villate, F., Moral, M., Valencia, V., 1997. Mesozooplankton community indicates climate changes in a shelf area of the inner Bay of Biscay throughout 1988 to 1990. J. Plankton Res. 19, 1617-1636.

Villate, F., Uriarte, I., Olivar, M.P., Maynou, F., Emelianov, M., Ameztoy, I., 2014. Mesoscale structure of microplankton and mesoplankton assemblages under contrasting oceanographic conditions in the Catalan Sea (NW Mediterranean). J. Mar. Syst. 139, 9-26. doi:10.1016/j.jmarsys.2014.05.004

Volis, S., Dorman, M., Blecher, M., Sapir, Y., Burdeniy, L., 2011. Variation partitioning in canonical ordination reveals no effect of soil but an effect of co-occurring species on translocation success in Iris atrofusca. J. Appl. Ecol. 48, 265-273. http: //dx.doi.org/10.1111/j.1365-2664.2010.01898.x.

Wouters, N., Dakos, V., Edwards, M., Serafim, M.P., Valayer, P.J., Cabral, H.N., 2015. Evidencing a regime shift in the North Sea using early-warning signals as indicators of critical transitions. Estuar. Coast. Shelf Sci. 152, 65-72. doi:10.1016/j.ecss.2014.10.017

Zarauz, L., Irigoien, X., Fernandes, J.A., 2008. Modelling the influence of abiotic and biotic factors on plankton distribution in the Bay of Biscay, during three consecutive years (2004-06). J. Plankton Res. 30, 857-872. doi:10.1093/plankt/fbn049

\section{List of Figures}

Figure 1: Map of the Bay of Biscay showing the location of the sampling stations of A) subsurface water environmental parameters (temperature, salinity, size-fractionated biomass of chlorophyll $a$ ), and B) the mesozooplankton community. Isobaths100 m (dotted line), $200 \mathrm{~m}$ (solid line) and $500 \mathrm{~m}$ (dashed line) are drawn.

Figure 2: Results of the annual (2003-2013) spatial interpolation of sub-surface temperature $\left({ }^{\circ} \mathrm{C}\right)$, salinity (psu), picophytoplankton $(\mathrm{chl} a<3 \mu \mathrm{m})$ biomass, nanophytoplankton $(3 \mu \mathrm{m}$ 
$<\operatorname{chl} l a<20 \mu \mathrm{m})$, and microphytoplankton $(\operatorname{chl} l a>20 \mu \mathrm{m})$ biomass $\left(\mu \mathrm{g} \cdot \mathrm{L}^{-1}\right)$ in the southern Bay of Biscay.

Figure 3: Interannual variation of the mean relative biomass of surface size-fractionated chlorophyll $a$ between 2003 and 2013 in the southern Bay of Biscay; in black for the picophytoplankton biomass $(<3 \mu \mathrm{m})$, in light grey for the nanophytoplankton biomass (3$20 \mu \mathrm{m})$ and in dark grey $(>20 \mu \mathrm{m})$ for the microphytoplankton biomass.

Figure 4: Interannual variation of the mesozooplankton abundance between 2003 and 2013: A) mean decadal and annual abundances (ind. $\mathrm{m}^{-3} \pm \mathrm{SD}$ ) of the entire mesozooplankton community and, B) stacked bar charts presenting the relative abundance of identified organisms belonging to copepods, gelatinous, other holoplankton and meroplankton groups on both the annual and decadal scale.

Figure 5: Annual spatial distribution of abundance (ind. $\mathrm{m}^{-3}$ ) for major families, genera or species contributing for more than $1.5 \%$ in abundance to the copepods community between 2003 and 2013 in the southern Bay of Biscay. The size of the pies is proportional to the total from each station throughout the decade.

Figure 6: Non-metric Multi-Dimensional Scaling (NMDS) on adult's copepods dataset in two panels, above: the plot of the sampling points and below, plot of the copepod taxa (only keeping the ones having correlation coefficient $>0.25$ ). Spatial location of each station was reported by their situation in the Bay of Biscay: coastal (C), continental shelf (Sh) and continental slope $(\mathrm{Sl})$. The choice of the three temporal groups was based on observations following Fig. 4A.

Figure 7: Venn diagram based on a variation partitioning presenting the explained variability of copepods community with two matrices, $\mathrm{H}$ and C. $H$ was built with subsurface 
temperature, deficit of potential energy and equivalent freshwater height and $\mathrm{C}$ with microphytoplankton (> $20 \mu \mathrm{m}$ ) biomass at the subsurface (the chl $a$ based-biomass $>20 \mu \mathrm{m}$ ). The external square represents the whole variation of the copepod community. Each circle represents the explanatory tables and values are the part of the variation explained by each explanatory table. The fraction "Int" is the intersection of the amount of variation explained by both types of explanatory variables. Statistically significant pure fraction of variation of copepod community is given in supplemental table 1 . 
Figure 1
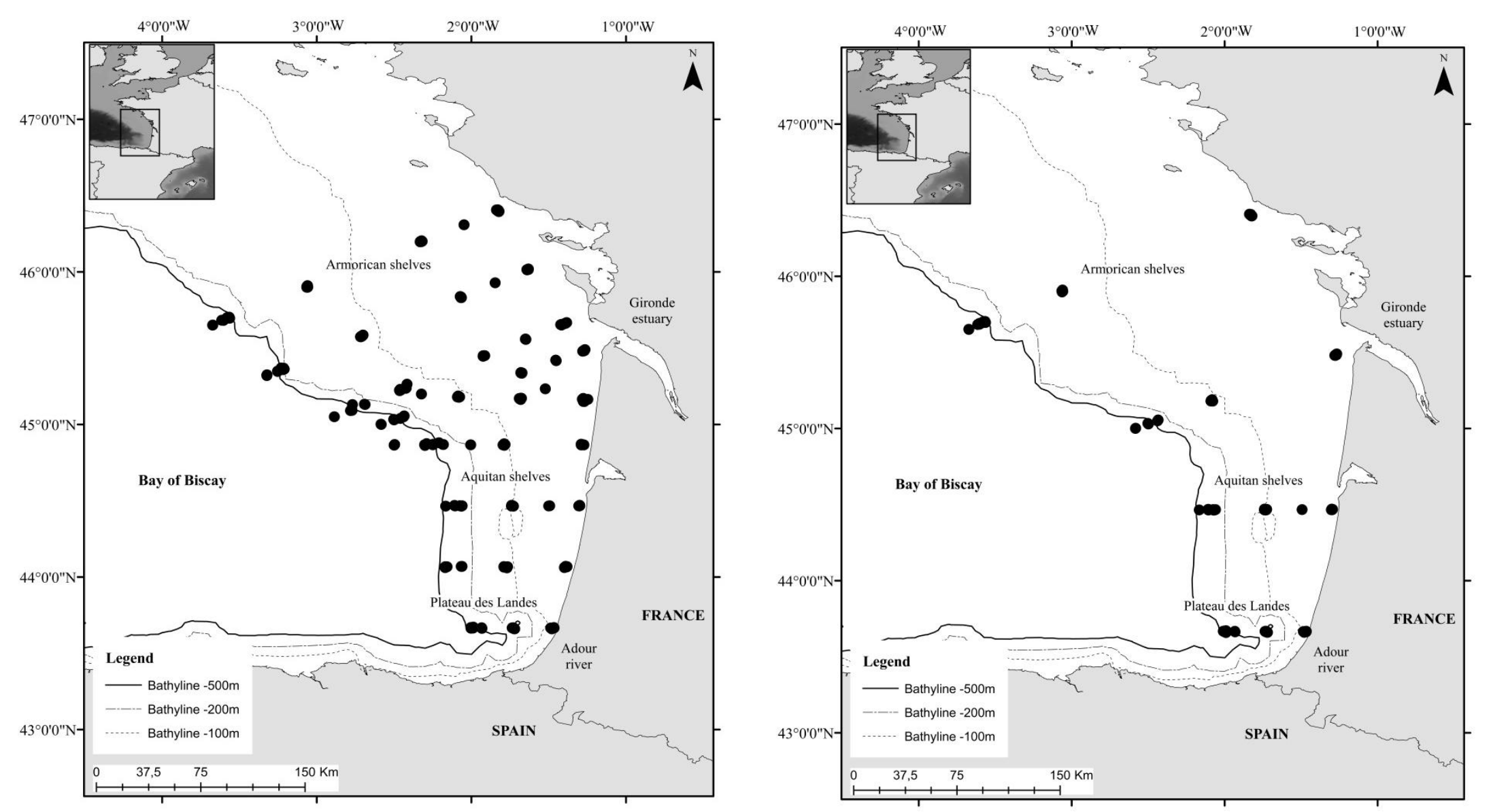
Figure 2

\section{Temperature $\left({ }^{\circ} \mathrm{C}\right)$}

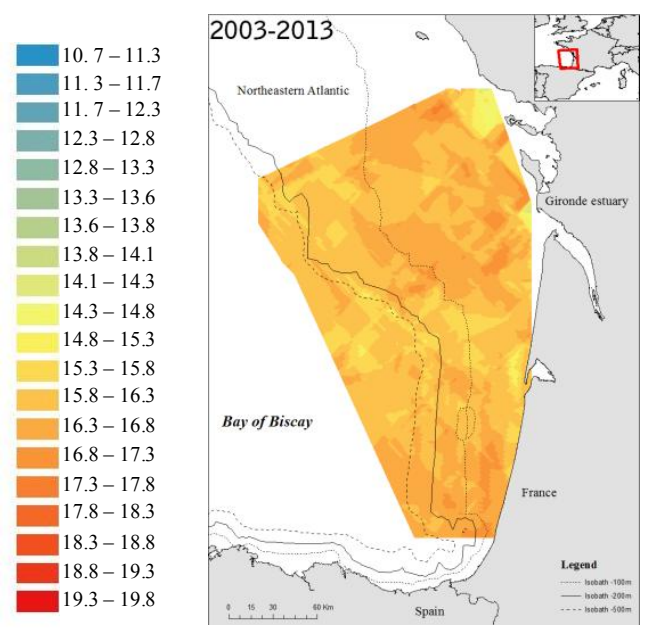

Chlorophyll $a<3 \mu \mathrm{m}\left(\mu \mathrm{g} \mathrm{L}^{-1}\right)$

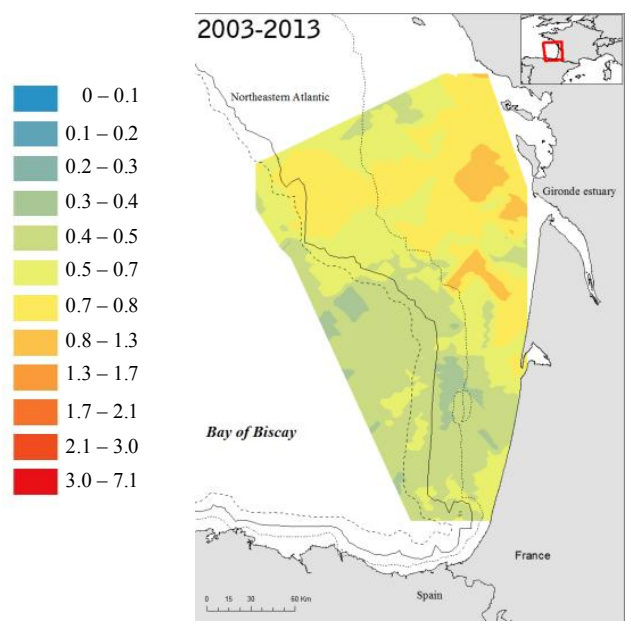

Chlorophyll $a>20 \mu \mathrm{m}\left(\mu \mathrm{g} \mathrm{L}^{-1}\right)$

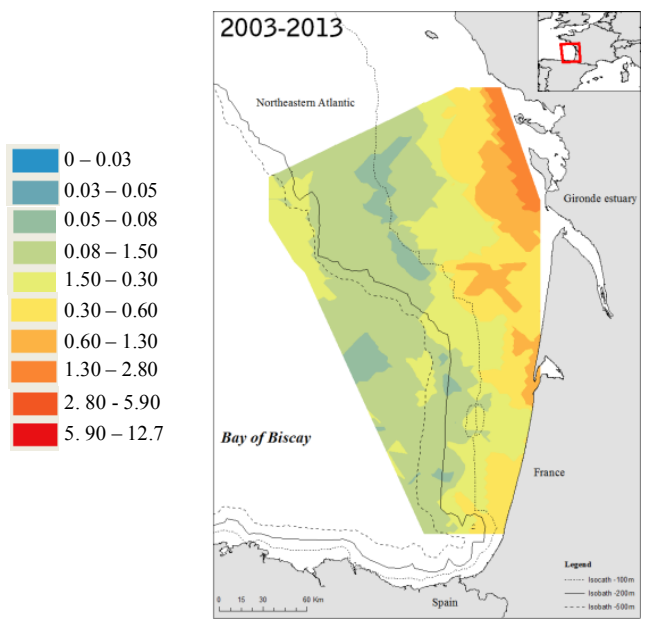

Salinity (PSU)

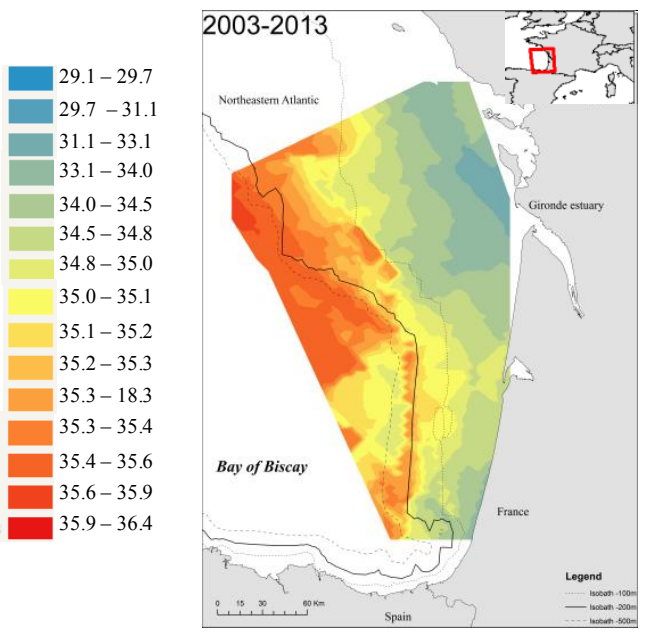

Chlorophyll $a$ [3-20] $\mu \mathrm{m}\left(\mu \mathrm{g} \mathrm{L}^{-1}\right)$

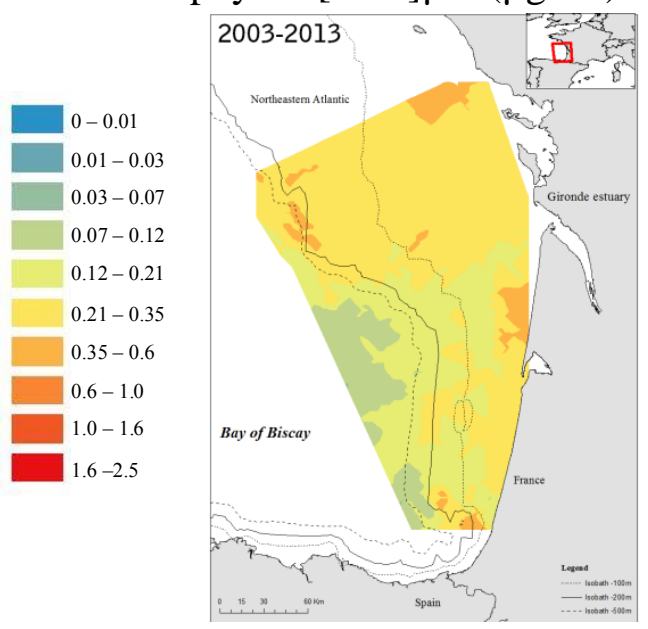


Figure 3

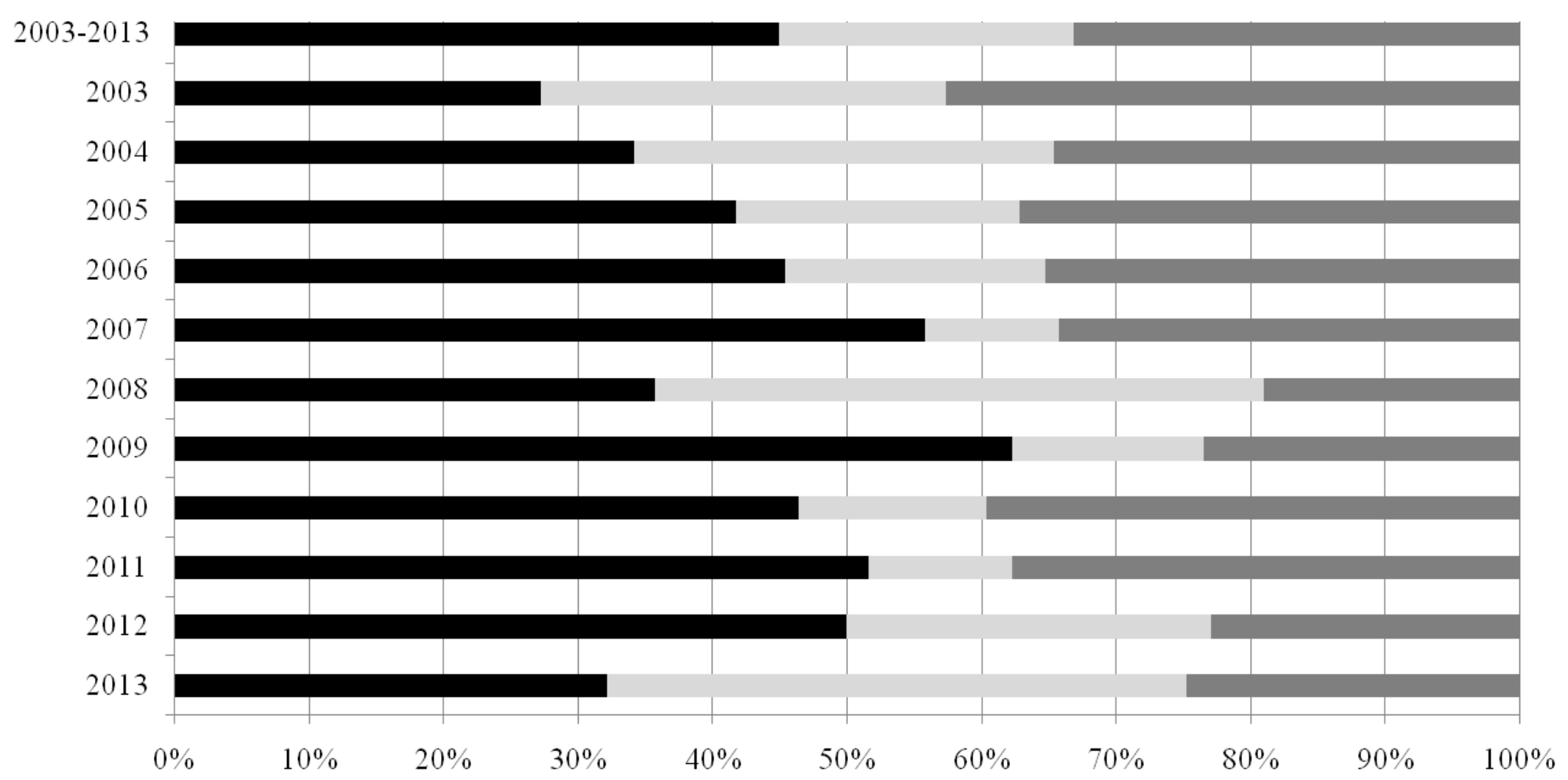

- Picophytoplankton $(<3 \mu \mathrm{m}) \quad$ Nanophytoplankton $(3-20 \mu \mathrm{m}) \quad \square$ Microphytoplankton $(>20 \mu \mathrm{m})$ 
Figure 4

A

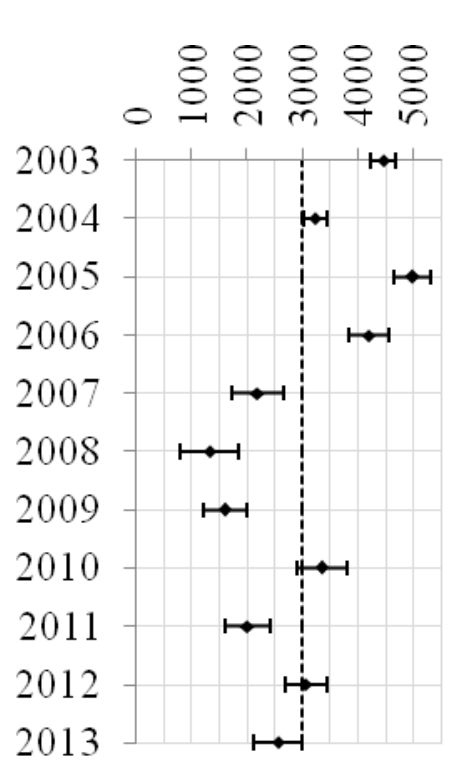

- Annual mean

-.----- Decadal mean
B

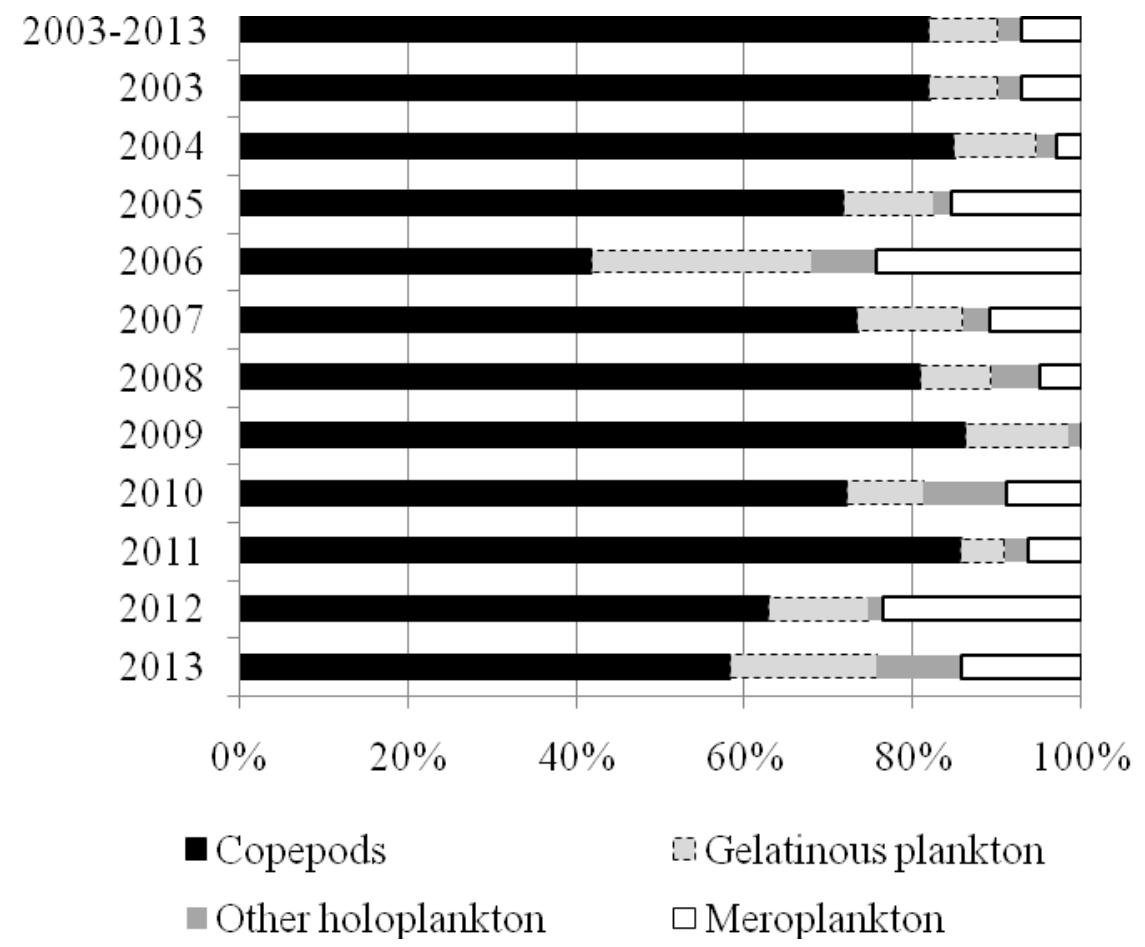


Figure 5
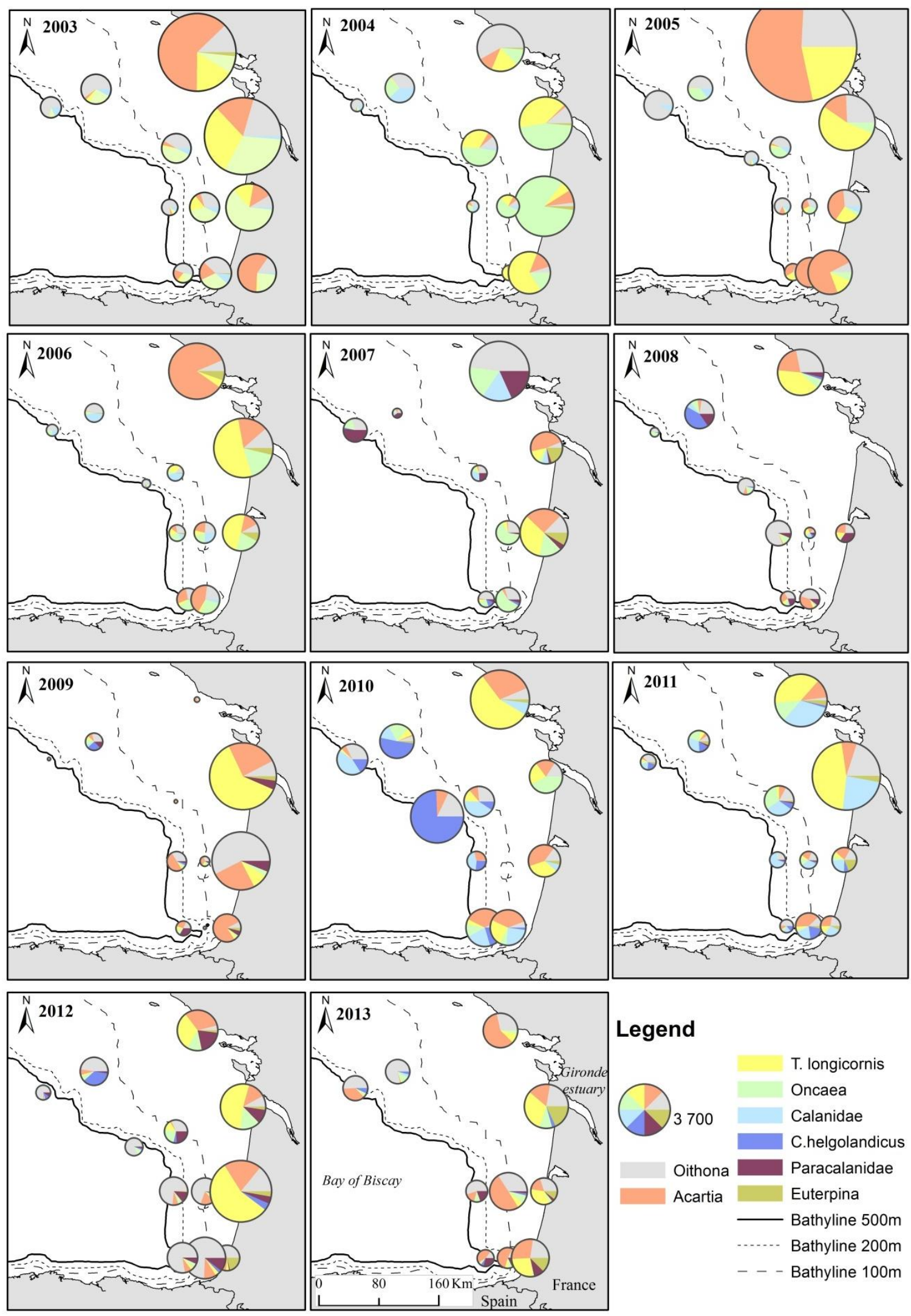

Legend

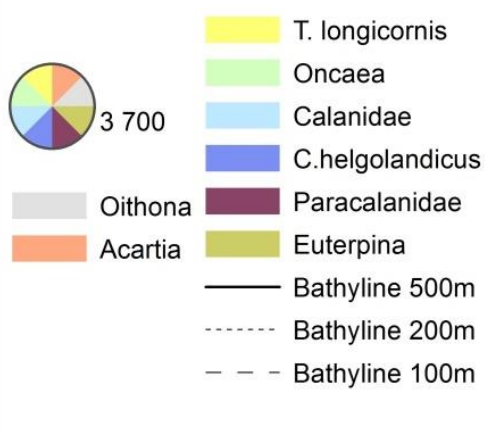

Figure 6 

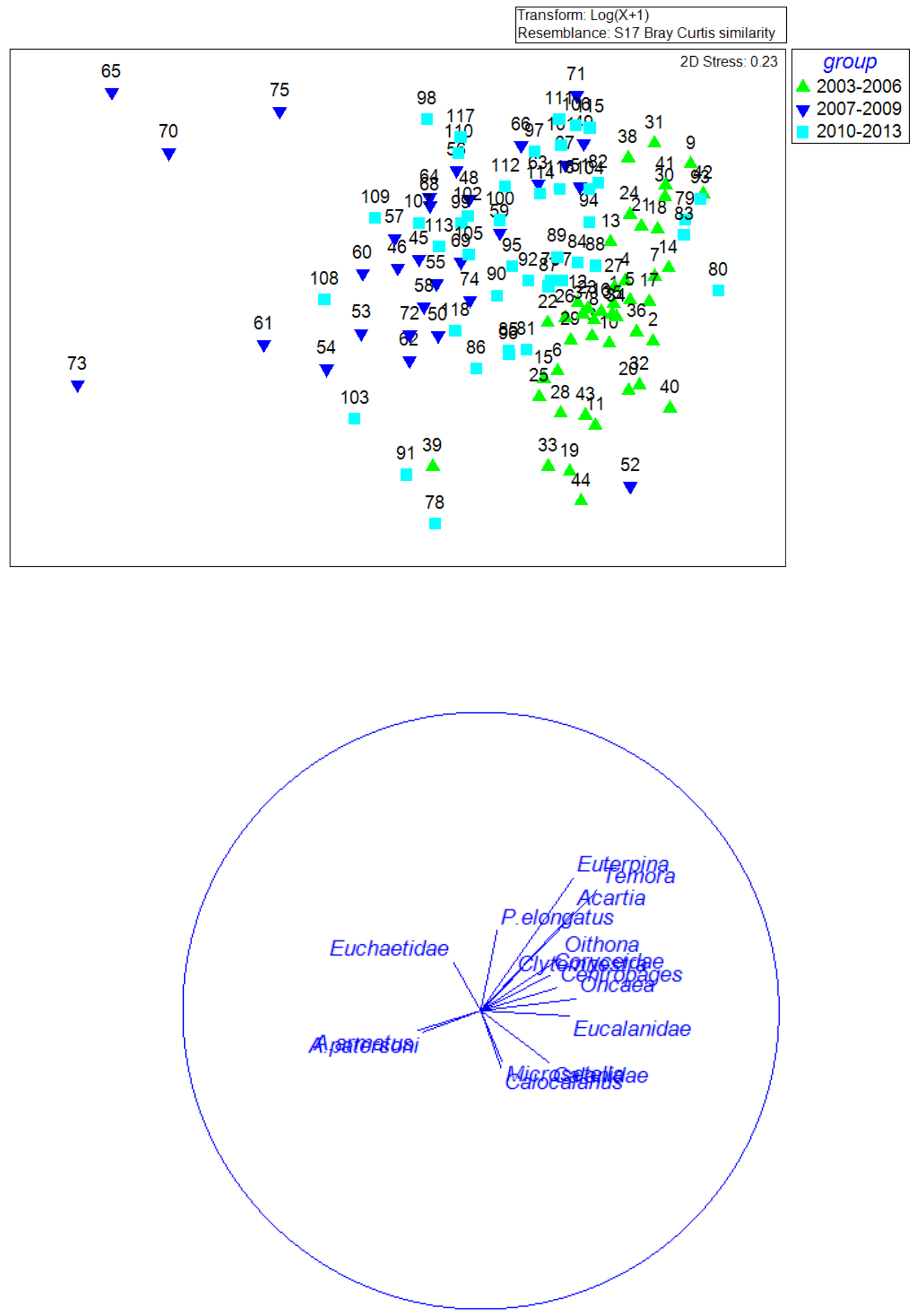


\section{Figure 7}

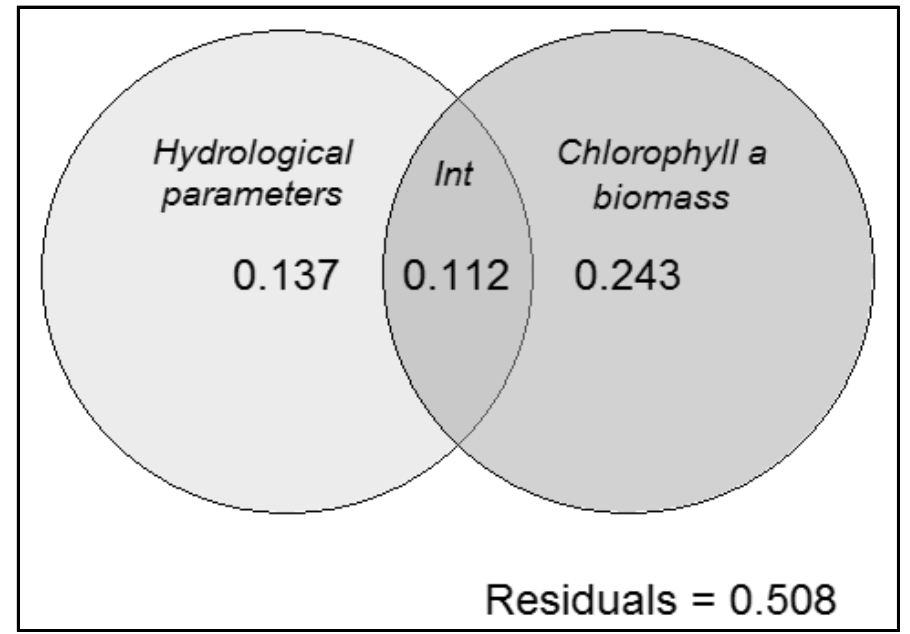

Table 1: Number of stations used in kriging (N.Station.Kriging) and multivariate (N.Station.VarPart) analysis per year start and the end dates of the surveys. 


\begin{tabular}{lcccc} 
Year & First Station & Last Station & N.Station.Kriging & N.Station.VarPart \\
\hline 2003 & 30 May & 09 June & 34 & 11 \\
2004 & 29 April & 10 May & 26 & 10 \\
2005 & 05 May & 16 May & 30 & 11 \\
2006 & 02 May & 13 May & 30 & 10 \\
2007 & 27 April & 08 May & 31 & 9 \\
2008 & 27 April & 09 May & 31 & 12 \\
2009 & 26 April & 09 May & 29 & 10 \\
2010 & 26 April & 09 May & 29 & 11 \\
2011 & 26 April & 09 May & 28 & 12 \\
2012 & 27 April & 13 May & 31 & 10 \\
2013 & 28 April & 16 May & 30 & \\
\hline
\end{tabular}

Table 2: Representative list of taxa and species of mesozooplankton found in the Bay of Biscay with distinction between major groups: copepods, gelatinous organisms $(\mathrm{G})$, other holoplankton $(\mathrm{H})$ and meroplankton $(\mathrm{M})$ organisms. For adult copepods, order affiliation is represented by Calanoida (Ca), Poecilostomatoida (P), Cyclopoida (Cy) and Harpaticoida (Ha) following by their relative percentage of abundance between 2003 and 2013 on copepods community. 
Table 2: continued

\begin{tabular}{llc}
\multicolumn{1}{c}{ Copepods } & \multicolumn{1}{c}{ Taxonomic level } & Order(\%) \\
Coryceidae & \multicolumn{1}{c}{ Family } & $\mathrm{P}(1.3)$ \\
Copepods & Taxonomic level & Order(\%) \\
\hline Acartia spp. & Genus & $\mathrm{Ca}(19.3)$ \\
Oithona spp. & Genus & $\mathrm{Cy}(18.5)$ \\
Temora longicornis & Species & $\mathrm{Ca}(17.4)$ \\
Copepodites & Development stage & $-(16)$ \\
Oncaea spp. & Genus & $\mathrm{P}(10.8)$ \\
Calanidae & Family & $\mathrm{Ca}(4.5)$ \\
Calanus helgolandicus & Species & $\mathrm{Ca}(2.8)$ \\
Paracalanidae & Family & $\mathrm{Ca}(2.2)$ \\
Euterpina acutifrons & Genus & $\mathrm{H}(1.6)$ \\
Centropages spp. & Genus & $\mathrm{Ca}(1.5)$ \\
Copepods nauplii & Development stage & $-(1.4)$ \\
\multicolumn{1}{c}{ Eucalanidae } & Family & $\mathrm{Ca}(1.3)$ \\
Metridia spp. & Genus & $\mathrm{Ca}(0.4)$ \\
Pseudocalanus elongatus & Species & $\mathrm{Ca}(0.5)$ \\
Microsetella spp. & Genus & $\mathrm{H}(0.1)$ \\
Candacia spp. & Genus & $\mathrm{Ca}(0.1)$ \\
Pleuromamma spp. & Genus & $\mathrm{Ca}(0.1)$ \\
Calocalanus spp. & Genus & $\mathrm{Ca}(0.1)$ \\
Clytemnestra spp. & Genus & $\mathrm{H}(<0.05)$ \\
& &
\end{tabular}

\begin{tabular}{|c|c|c|}
\hline Other taxonomic groups & Taxonomic level & Group \\
\hline Bivalvia larvae & Class & M \\
\hline Other taxonomic groups & Taxonomic level & Group \\
\hline Appendicularia & Class & $\mathrm{G}$ \\
\hline Siphonophorae & Order & $\mathrm{G}$ \\
\hline Indetermined Cnidaria & Phylum & $\mathrm{G}$ \\
\hline Chaetognata & Phylum & $\mathrm{G}$ \\
\hline Salpida & Order & $\mathrm{G}$ \\
\hline Doliolida & Order & $\mathrm{G}$ \\
\hline Annelida larvae & Phylum & M \\
\hline Cirripedia & Infra-class & M \\
\hline Decapoda & Order & M \\
\hline Scaphopoda & Class & M \\
\hline Gastropoda larvae & Class & M \\
\hline Enteropneusta & Class & M \\
\hline Anthozoa larva & Class & M \\
\hline Ectoprota & Phylum & M \\
\hline Cyphonauta larvae & Development stage & M \\
\hline Bryozoa & Phylum & M \\
\hline Echinodermata larvae & Phylum & M \\
\hline Hydrozoa & Class & M \\
\hline Scyphozoa & Class & M \\
\hline
\end{tabular}




$\begin{array}{ccc}\text { Aegistus spp. } & \text { Genus } & \mathrm{H}(<0.05) \\ \text { Aetideus armatus } & \text { Species } & \mathrm{Ca}(<0.05) \\ \text { Euchaetidae } & \text { Family } & \mathrm{Ca}(<0.01) \\ \text { Rhincalanidae } & \text { Family } & \mathrm{Ca}(<0.01) \\ \text { Anomalocera patersoni } & \text { Species } & \mathrm{Ca}(<0.01)\end{array}$

Ostracoda
Isopoda
Mysida
Amphipoda
Euphausiacea
Cladocera
Chordata
Cumacea

Class

$\mathrm{H}$

Foraminifera

Order

$\mathrm{H}$

$\mathrm{H}$

Order H

Order $\quad \mathrm{H}$

Anomalocera patersoni

Table 3: Results of the similarity percentage (SIMPER) analysis based on spring adult copepods matrix in the Bay of Biscay between 2003 and 2013.

\begin{tabular}{lclclc}
\multicolumn{2}{c}{ Group [2003-2006] } & \multicolumn{2}{c}{ Group [2007-2009] } & \multicolumn{2}{c}{ Group [2010-2013] } \\
\hline \multicolumn{2}{c}{ Average similarity: 66.83} & \multicolumn{2}{c}{ Average similarity: 52.32 } & \multicolumn{2}{c}{ Average similarity: 59.89 } \\
\hline Genus/Species/Family & Contrib\% & Genus/Species/Family & Contrib\% & Genus/Species/Family & Contrib\% \\
\hline Oithona spp. & 22.4 & Oithona spp. & 24.37 & Oithona spp. & 24.02 \\
Oncaea spp. & 17.8 & Acartia spp. & 17.96 & Acartia spp. & 19.21 \\
Acartia spp. & 13.04 & Oncaea spp. & 17.1 & Temora longicornis & 13.24 \\
Temora longicornis & 12.2 & Paracalanidae & 15.16 & Oncaea spp. & 10.96 \\
Eucalanidae & 11.94 & Temora longicornis & 7.77 & Calanus helgolandicus & 7.95 \\
Calanidae & 10.54 & Coryceidae & 3.76 & Calanidae & 6.97 \\
Centropages spp. & 5.31 & Calanus helgolandicus & 3.04 & Paracalanidae & 4.84 \\
& & Calanidae & 2.9 & Euterpina acutifrons & 4.11 \\
\hline
\end{tabular}


Table 4: Results of the dissimilarity percentage (SIMPER) analysis based on spring adult copepods matrix in in the Bay of Biscay between 2003 and 2013.

\begin{tabular}{|c|c|c|c|c|c|}
\hline \multicolumn{2}{|c|}{ Groups [2003-2006] and [2007-2009] } & \multicolumn{2}{|c|}{ Groups $[2003-2006]$ and $[2010-2013]$} & \multicolumn{2}{|c|}{ Groups [2007-2009] and [2010-2013] } \\
\hline \multicolumn{2}{|c|}{ Average dissimilarity: 52.01} & \multicolumn{2}{|c|}{ Average dissimilarity: 45.51} & \multicolumn{2}{|c|}{ Average dissimilarity: 46.88} \\
\hline Genus/Species/Family & Contrib\% & Genus/Species/Family & Contrib\% & Genus/Species/Family & Contrib\% \\
\hline Eucalanidae & 11.04 & Eucalanidae & 11.29 & Temora longicornis & 10.09 \\
\hline Paracalanidae & 10.49 & Calanus helgolandicus & 9.44 & Calanidae & 9.78 \\
\hline Temora longicornis & 9.62 & Calanidae & 8.55 & Calanus helgolandicus & 9.05 \\
\hline Calanidae & 8.59 & Temora longicornis & 8.46 & Paracalanidae & 8.79 \\
\hline Acartia spp. & 8.2 & Acartia spp. & 7.85 & Acartia spp. & 8.39 \\
\hline Oncaea spp. & 7.2 & Oncaea spp. & 7.67 & Euterpina acutifrons & 7.48 \\
\hline Centropages spp. & 6.87 & Paracalanidae & 7.15 & Oncaea spp. & 7.38 \\
\hline Coryceidae & 6.29 & Euterpina acutifrons & 7.1 & Oithon aspp. & 6.31 \\
\hline Oithona spp. & 5.77 & Centropages spp. & 6.92 & Centropages spp. & 5.99 \\
\hline Euterpina acutifrons & 4.98 & Coryceidae & 6.49 & Coryceidae & 5.97 \\
\hline Metridia spp. & 4.54 & Metridia spp. & 4.79 & Metridia spp. & 4.71 \\
\hline Calanus helgolandicus & 4.4 & Oithona spp. & 3.74 & Pseudocalanus elongatus & 3.46 \\
\hline Candacia armata & 2.65 & Microsetella spp. & 3.06 & Candacia armata & 3.04 \\
\hline
\end{tabular}

Table 5: Variables best explaining the copepod community based on the forward selection. Cumulative explained variance, " $F$ " statistic and pvalues are reported. Sums of all eigenvalues (reported) is used as a tool to assess how well specific selection of explanatory variables explains the variance in the copepod community." 
Variables order

Eigenvalues

sums

Sub-Surface Chla>20 $\mu \mathrm{m}$ (Microphytoplankton)

Based biomass

Equivalent fresh water height

Deficit of potential energy

Sub-surface temperature

0.35

0.35

0.42

0.45

0.49

Codes:0 ‘***’;0.001 ‘**’;0.01 ‘*’
F

65.28

15.47

$7.50 *$

$8.84 \quad * *$ 


\section{List of supplemental figures}

Supplemental figure S1: Annual interpolated maps of results of the annual spatial interpolation of sub-surface temperature measures $\left({ }^{\circ} \mathrm{C}\right)$, performed for each year between 2003 and 2013 in the southern Bay of Biscay. Thanks to a non-parametric multiple pairwise comparison of mean ranks applied for all years, significant differences of sub-surface temperature according to year are indicated by letters.

Supplemental figure S2: Annual interpolated maps of results of the spatial interpolation of sub-surface salinity (PSUpsu) performed for each year between 2003 and 2013, in the southern Bay of Biscay.

Supplemental figure S3: Annual interpolated maps of results of the spatial interpolation of sub-surface picophytoplankton $(\operatorname{chl} a<3 \mu \mathrm{m})$ biomass $\left(\mu \mathrm{g} . \mathrm{L}^{-1}\right)$ performed for each year between 2003 and 2013, in the southern Bay of Biscay. Thanks to a non-parametric multiple pairwise comparison of mean ranks applied for all years, significant differences of sub-surface picophytoplankton biomass according to year are indicated by letters.

Supplemental figure S4: Annual interpolated maps of results of the spatial interpolation of sub-surface nanophytoplankton $([3-20] \mu \mathrm{m})$ biomass $\left(\mu \mathrm{g} . \mathrm{L}^{-1}\right)$ performed for each year between 2003 and 2013, in the southern Bay of Biscay. Thanks to a non-parametric multiple pairwise comparison of mean ranks applied for all years, significant differences of sub-surface nanophytoplankton biomass according to year are indicated by letters.

Supplemental figure S5: Annual interpolated maps of Results of the spatial interpolation of sub-surface microphytoplankton $(\operatorname{chl} a>20 \mu \mathrm{m})$ biomass $\left(\mu \mathrm{g} . \mathrm{L}^{-1}\right)$ performed for each year between 2003 and 2013, in the southern Bay of Biscay. Thanks to a non-parametric multiple pairwise comparison of mean ranks applied for all years, significant differences of sub-surface microphytoplankton biomass according to year are indicated by letters. 
Supplemental figure S6: Spatial distribution of abundance (ind. $\mathrm{m}^{-3}$ ) of copepods nauplii, copepodites and Harpacticoida, Poecilostomatoida, Cyclopoida, Calanoida (orders) between 2003 and 2013 in the southern Bay of Biscay. The size of the pies is proportional to the total abundance of from each station throughout the decade. Significant differences in abundance

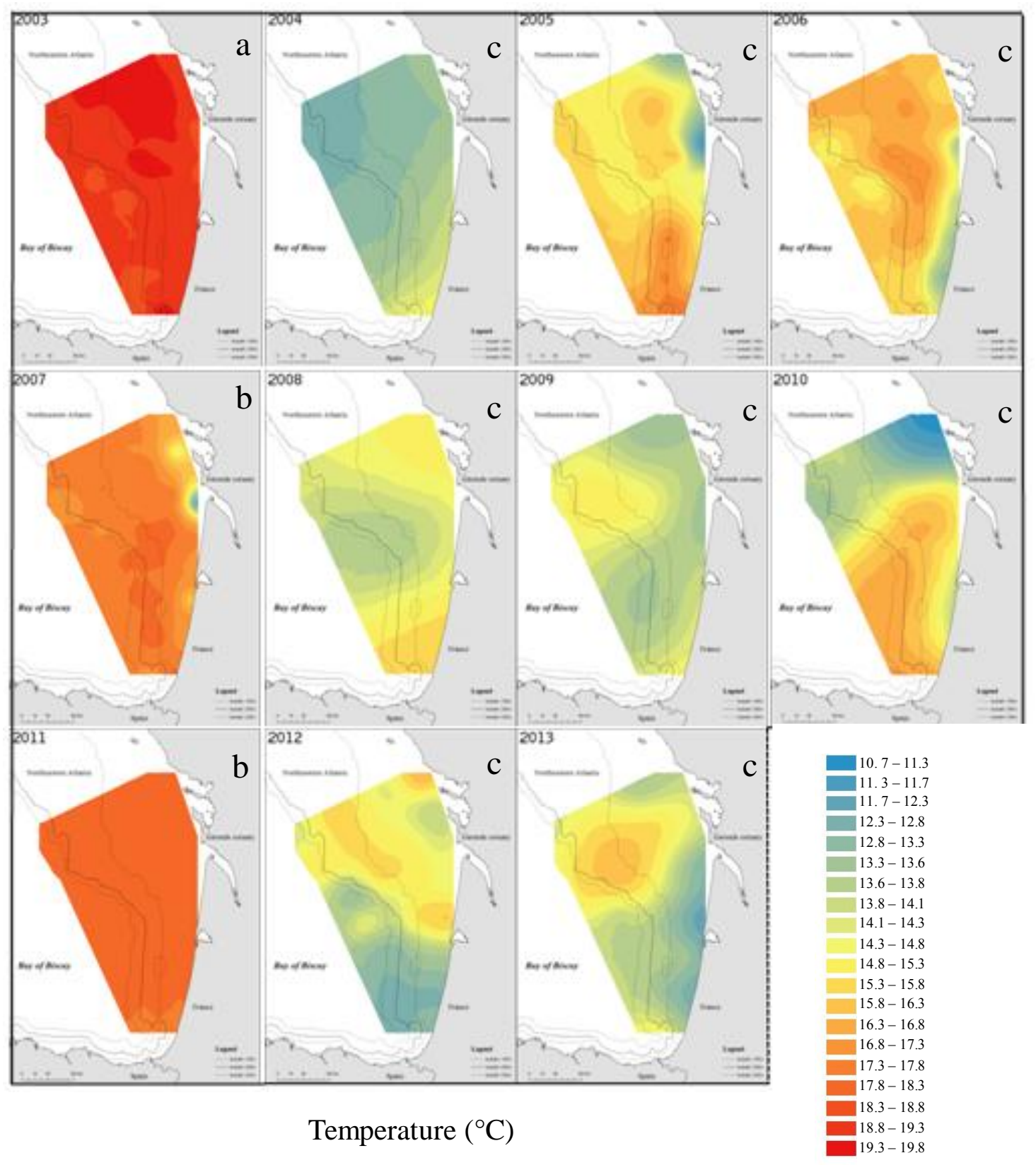

according to year are indicated by letters.

\section{Supplemental figure 1:}




\section{Supplemental figure 2:}

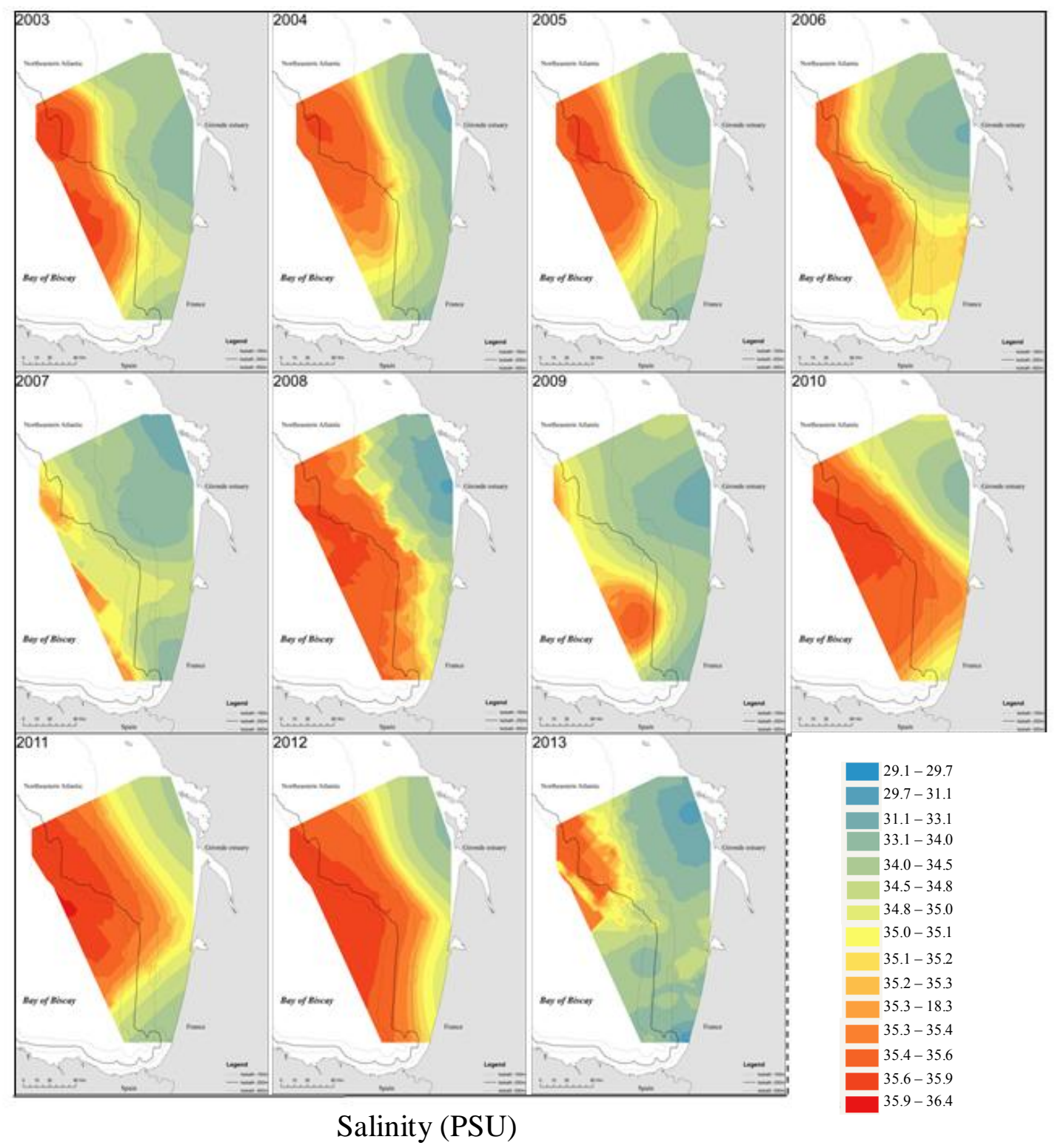

Supplemental figure 3: 


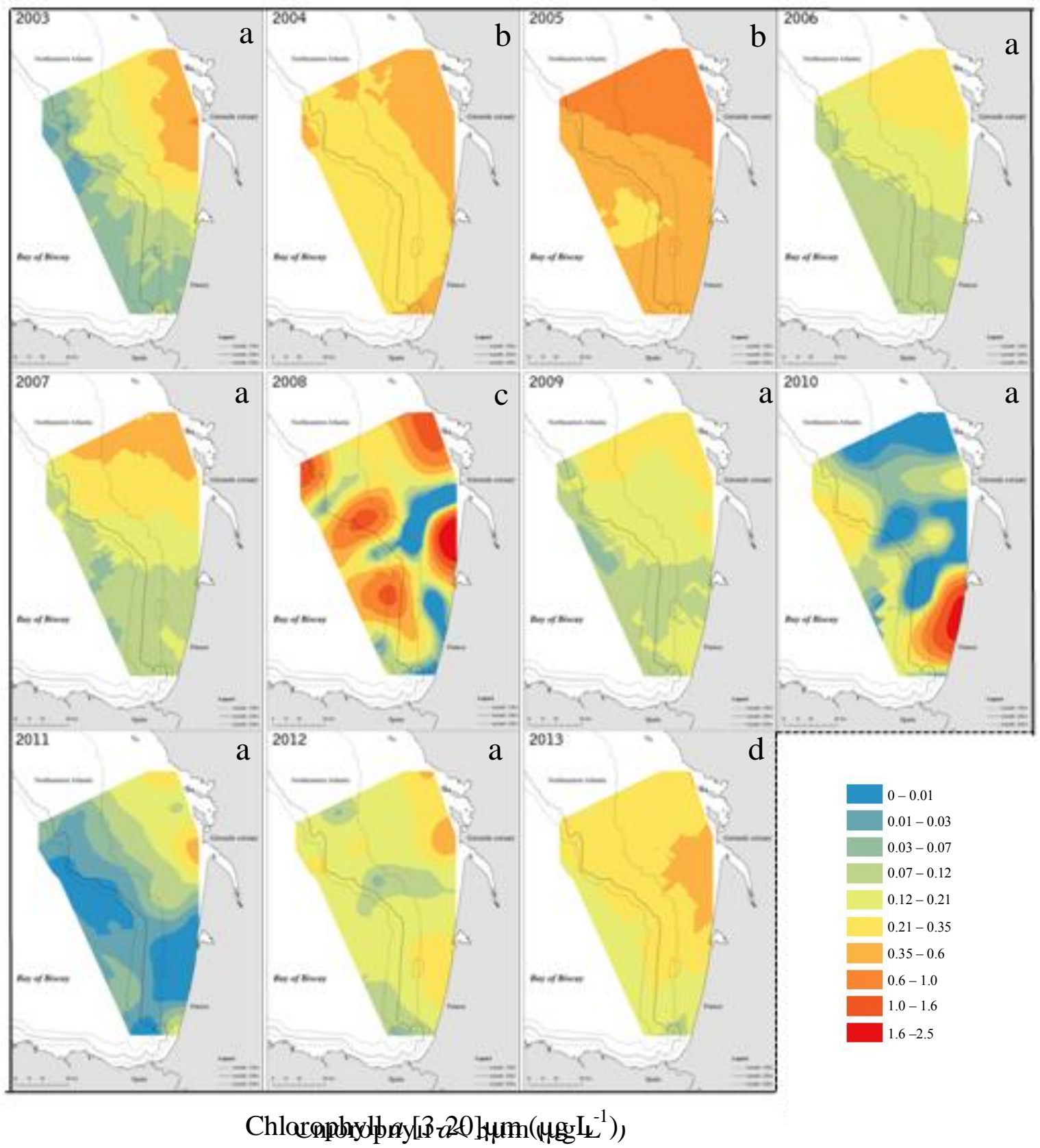

Supplemental figure 4: 


\section{Supplemental figure 5:}

\section{Supplemental figure 6:}

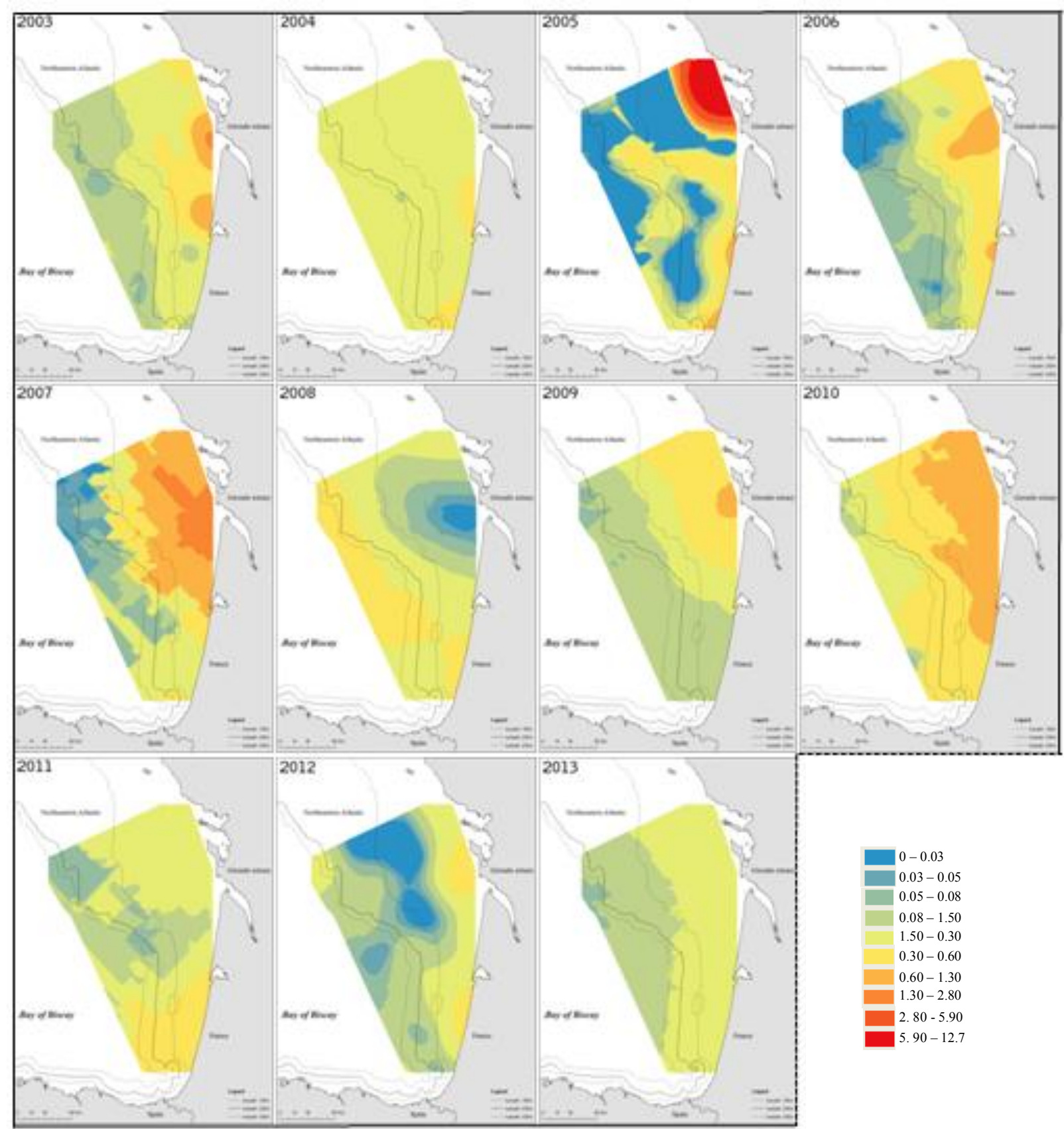

Chlorophyll $a>20 \mu \mathrm{m}\left(\mu \mathrm{g} \mathrm{L}^{-1}\right)$ 

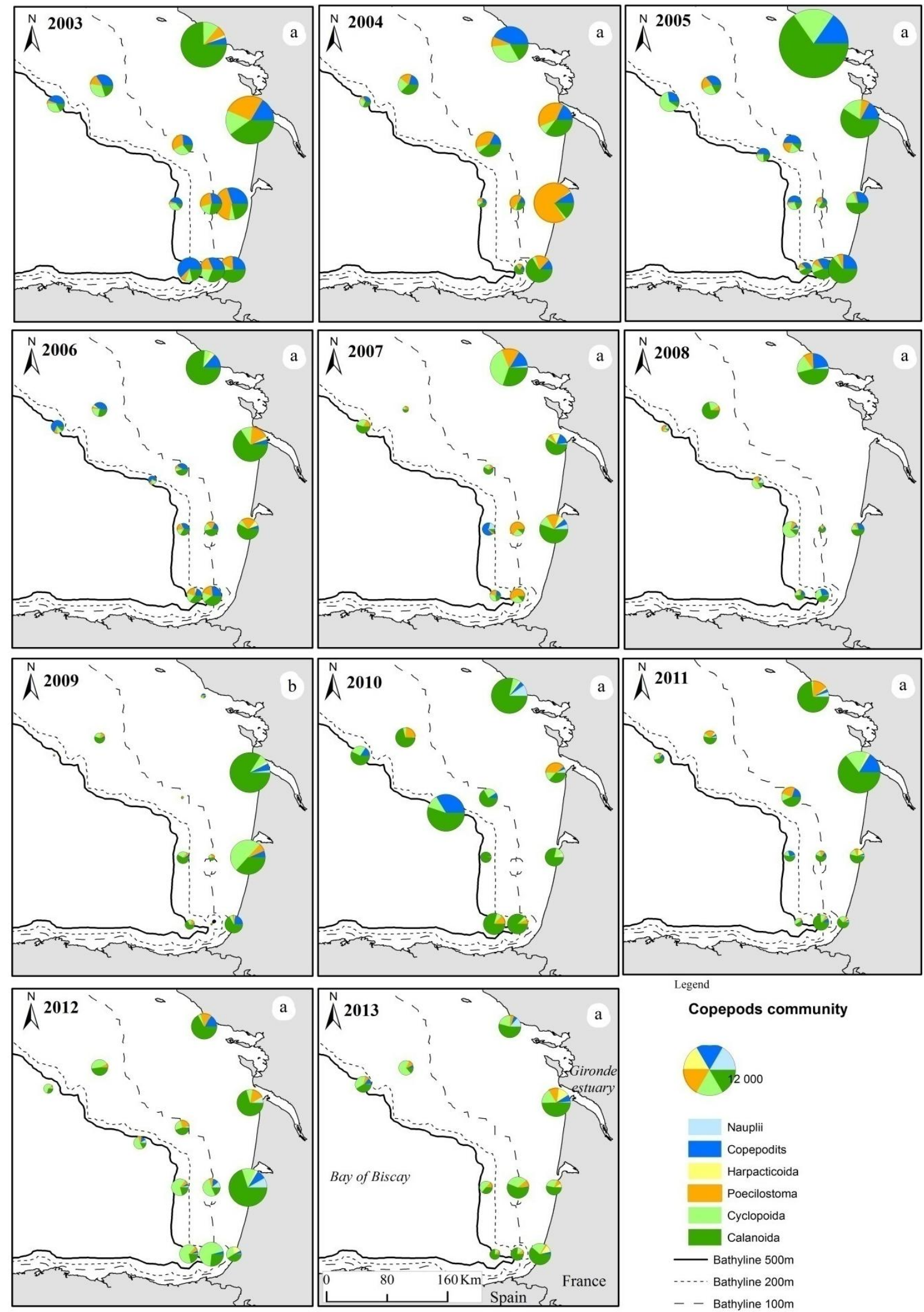

Copepods community
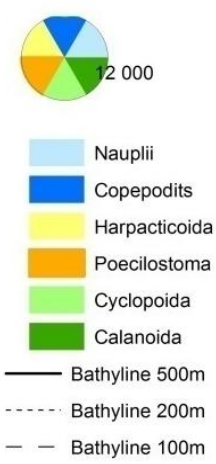


\section{List of supplemental figure :}

Supplemental table 1: Identification of copepod community drivers by variation partitioning analysis based on ordination analyses. Matrix $\mathrm{H}$ includes environmental variables (subsurface temperature values, deficit of potential energy and equivalent freshwater height), matrix $\mathrm{C}$ includes the chlorophyll $a>20 \mu \mathrm{m}$ biomass (microphytoplankton biomass). Multivariate analysis, covariables, component of variation, explained variance and statistical p-values are reported.

\begin{tabular}{lllll} 
Analysis & $\begin{array}{c}\text { Constraining } \\
\text { variable }\end{array}$ & $\begin{array}{c}\text { Component } \\
\text { of the } \\
\text { variation }\end{array}$ & $\begin{array}{c}\text { Explained } \\
\text { variance }\end{array}$ & p-value \\
\hline ACP & - & - & & \\
RDA & $\mathrm{H}$ & $\mathrm{H}+\mathrm{HC}$ & 0.24 & $* * *$ \\
RDA & $\mathrm{C}$ & $\mathrm{C}+\mathrm{HC}$ & 0.35 & $* * *$ \\
RDA & $\mathrm{H}+\mathrm{C}$ & $\mathrm{H}+\mathrm{C}+\mathrm{HC}$ & 0.49 & $* * *$ \\
RDAp & $\mathrm{H}$ & $\mathrm{H}$ & 0.13 & $* * *$ \\
RDAp & $\mathrm{C}$ & $\mathrm{C}$ & 0.24 & $* *$ \\
\hline
\end{tabular}

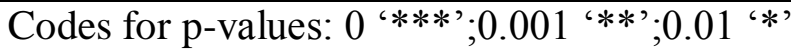

